\title{
Kalkınma Planlarında Yer Alan Orman Köylüsüne İlişkin Politikaların Zamansal Değişimi
}

\author{
Hikmet Batuhan GÜNŞEN ${ }^{1 *}$, Erdoğan ATMIŞ ${ }^{1}$ \\ ${ }^{1}$ Bartın Üniversitesi, Bartın Orman Fakültesi, Orman Mühendisliği Bölümü,74100, Bartın
}

\section{Öz}

Türkiye'de toplumun farklı kesimleri arasındaki gelir dağılımı eşitsizliği uzun zamandan beri varlığını sürdürmektedir. Orman köylerinin sahip olduğu zor yaşam şartları, orman köylüsünün ülke genelinde en düşük gelire sahip kesimi olmasına da neden olmuştur. Bu nedenle zaman içinde orman köylüsünü kalkındırma iddiasını taşıyan çeşitli politikalar oluşturulmuştur. Bu politikaların önemli bir kısmını ülke kalkınma planlarında görmek mümkündür. Bu çalışma; orman köylüsüyle ilgili politikalara ülke kalkınma planlarında ne derecede yer verildiğini ortaya koymak ve ilk kalkınma planından günümüze kadar geçen sürede kalkınma planlarında yer alan orman köylüleriyle ilgili politikaların zamana göre değişimini analiz etmek amacıyla yapılmıştır. Bunun için içerik analizinden yararlanılmış, orman köylüsüyle ilgili belirlenmiş sözcük ve kavramların kalkınma planlarında ne kadar sıklıkla kullanıldığı ve orman köylüsünün kalkındırılmasıyla ilgili hangi politikaların oluşturulduğu belirlenerek bunların gerçekleştirilip gerçekleştirilmedikleri sorgulanmıştır. Sonuç olarak; orman köylüsünün kalkındırılması için kooperatifleşme, kredi ve fonlar, yasal haklar gibi araçlar kullanılmasına karşın başarılı olunamadığı görülmüştür. Bu başarısızlıktaki en büyük etmen ise; gittikçe liberalleşen ülke politikalarının ormanlar ve orman köylüsünü koruma ile kalkındırma konularındaki zamanla artan ilgisizliğidir.

Anahtar Kelimeler: İçerik analizi, kırsal kalkınma, ormancılık, planlama, yönetim.

\section{Temporal Changes of Policies Regarding Forest Villagers in Development Plans}

\begin{abstract}
Income inequality between different sections of society has been in existence for a long time in Turkey. Difficult living conditions of forest villages also caused the forest villagers to be in the segment with the lowest income across the country. For this reason, various policies that claim the development of the forest villagers have been developed over time. It is possible to see a significant part of these policies in the country's development plans. This study was carried out to reveal to what extent the policies related to the forest villagers are included in the country's development plans and to analyse the temporal change of policies related to the forest villagers in the development plans from the first development plan to the present day. For this purpose, content analysis was used, and how often the determined words and concepts related to the forest villagers were used in the development plans, and what policies were established for the development of forest villagers were determined and whether they were realized or not was questioned. As a result, it was observed that although tools such as cooperatives, loans and funds, and legal rights were used for the development of the forest villagers, they were not successful. The biggest factor in this failure is the gradually increasing indifference of the increasingly liberalized national policies in the fields of protection and development of forests and forest villagers.
\end{abstract}

Keywords: Administration, content analysis, forestry, planning, rural development. 


\section{Giriş}

18. yüzyılın ikinci yarısında gerçekleşen sanayi devrimiyle birlikte ülkeler arasındaki kalkınmışlık farkı kendini iyice göstermiştir (Yanar, 2014: 3). Kalkınma düzeylerindeki bu farklılıklardan dolayı ülkeleri; gelişmiş ülkeler, gelişmekte olan ülkeler ve az gelişmiş ülkeler olarak sınıflandırmak mümkündür. Az gelişmiş ülkeler genel olarak ekonomik, demografik, sosyal ve teknolojik özellikleri bakımından gelişmiş ülkelere göre daha geri durumdadır (Tolunay ve Korkmaz, 2003: 195). Bundan dolayı da az gelişmiş ülkeler kalkınmalarını tamamlayabilmek için büyük çaba sarf etmektedirler. Kalkınma genel olarak bir yandan ülke ekonomisinin gücünün arttırılması diğer yandan da eğitim, kültür ve sağlık gibi sosyal hizmetlerin geliştirilmesini amaçlamaktadır. Tüm bunlar yapılırken de gelir dağılımında sosyal adaleti ve bölgeler arası dengeyi sağlamak şarttır. Bunun için de kalkınma çalışmalarının bir plan dâhilinde yapılması gerekmektedir (Güven, 1995: 7).

Türkiye'de planlamayla ilgili ilk deneyimler 1930'lu yılların başında yaşanmıştır. 1929 yılında başlayarak tüm dünyayı etkisi altına alan Büyük Buhran ve ülke ekonomisinin istenen düzeyde olmaması Türkiye'nin devletçi ekonomi politikalarına daha fazla eğilim göstermesine neden olmuştur (Yücel, 2014: 5). Bu yıllarda benimsenen Devletçilik uygulamaları, ekonomide önceliği sanayi kesimine vermiştir. Böylelikle, devletin kalkınma faaliyetlerine doğrudan müdahale ettiği planlı sanayileşme dönemine geçilmiştir. Bu dönem kendi içinde Birinci Beş Yıllık Sanayi Planı (1934-1938) ve İkinci Beş Yıllık Sanayi Planı (1938-1942) dönemleri olarak ikiye ayrılmaktadır (Polatoğlu, 2017: 55).

Merkezi devletin bir sanayi yatırımları listesini içeren Birinci Beş Yıllık Sanayi Planı 9 Ocak 1934 tarihinde hükümetçe onaylanmış ve 1934-1938 yılları arasında uygulanmıştır. Planda ana hammaddesi ülkede yetişen ya da kısa sürede ülke içinden sağlanması mümkün görülen, büyük sermaye ve teknik güç gerektiren sanayi dallarına öncelik verilmiştir (Tecer, 2006: 93). Bunlar dokuma, maden, selüloz, kimya ve seramik sanayileridir (Özyurt, 1981: 132). Böylelikle dünyada Büyük Buhranın etkilerinin devam etmesine rağmen Türkiye ekonomisi kendi öz kaynaklarıyla kalkınma ve sanayileşme çalışmalarını başlatabilmiştir (Uçkaç, 2010: 426). Plan beklenenin de ötesinde iyi sonuçlar vermiş, bitiminde daha kapsamlı olan İkinci Beş Yıllık Sanayi Planı hazırlanmıştır. 19381942 dönemini kapsayan bu plan ile ülke genelinde birçok fabrika ve tesis kurulması öngörülmüştür. Bu tesisler için gerekli sanayi girdilerinin ülke içinden karşılanması esas alınmıştır. Planda madencilik, maden kömürü ocakları, demir çelik, hidroelektrik santralleri, toprak sanayii, gıda maddeleri ve kimya sanayine yönelik yatırımlara ağırlık verilmiştir. Planın birinci sanayi planından en önemli ayrımı yatırım mallarının üretimine daha fazla öncelik verirken ihracatı da amaçlamış olmasıdır. Ancak İkinci Dünya Savaşının etkisiyle İkinci Beş Yıllık Sanayi Planı uygulanamamıştır (Güven, 1995: 27). Her iki sanayi planında da öncelikli olarak ele alınan sanayi kollarının bir kısmında ormancılığın ve ormanlardan elde edilen odun hammaddesinin büyük katkıları olmuştur. 1937 yılında 3116 sayılı Orman Kanunu ile kurulan devlet orman işletmeleri (günümüzdeki adı orman işletme müdürlüğü) sanayi kalkınma planlarında belirlenen sanayi kollarının maden direği, demiryolu traversi, tel direk, ambalaj kerestesi, kâğıtlık odun, mobilya kerestesi, fıçı üretimi, reçine, selüloz, katran vb. ihtiyaçlarını sağlamış ve bu dönemde önemli sayılacak miktarda ihracat da yapılmıştır (Özdönmez vd., 1996: 95; Günay, 2003: 98; Gümüş, 2018: 116-225). Tüm bu ihtiyaçlar, ormanlardan odun hammaddesi elde edilmesi sürecinde, orman köylüsünün istihdam edilmesiyle karşılanmıştır.

Bu iki plan sadece devletin yapacağı sanayi yatırımlarını kapsadığı için genel ve makro düzeyde olamamıştır. Tüm ülke düzeyinde, sadece ekonomik değil sosyal ve kültürel kalkınmayı da hesaba katan ve bilimsel tekniklere göre yapılan kalkınma planlarının hazırlanarak uygulamaya konulması ise 1960'lı yılların başını bulmuştur.

1950-1960 yılları arasında iktidarda olan Demokrat Parti, liberal ekonomi politikalarını bilinçsizce uygulamış, ülkenin kaynak ve olanaklarını da gelişigüzel ve savurganca kullanmıştır (Baytal, 2007: 567; Takım, 2012: 182). Tüm bunlara bağlı olarak da gelişmeyi engelleyen darboğazlar aşılamamıştır. Bu durum özellikle de sosyal alandaki gelir dağılımı eşitsizliklerini daha da arttırmıştır (Güven, 1995: 29). Bunların üstüne Demokrat Partinin liberal ve muhafazakâr söylemlerinin Atatürk ilke ve devrimlerini tehlikeye soktuğu yolundaki kaygıların artması sonucunda 27 Mayıs 1960 darbesi olmuştur (Demir ve Üzümcü, 2002: 159). Darbe sonrasında ülkenin istikrarının bozulmasına iktidarın plansız uygulamalarının sebep olduğu düşünülerek uzun vadeli bir ekonomik planın yapılmasına karar verilmiştir (Tüzünkan, 2015: 91). 30 Eylül 1960’ta Devlet Planlama Teşkilatı kurulmuş ve hazırlanan 1961 Anayasasının 41. ile 129. maddelerinde; ülkede ekonomik, sosyal ve kültürel kalkınmanın plana bağlanması ve kalkınmanın planlı olması benimsenmiştir. Böylelikle Türkiye’de 1963 yılında Birinci Beş Yıllık Kalkınma Planı yayınlanarak planlı döneme geçilmiştir. Kalkınmanın planlı olma anlayışı 1982 Anayasası'nın 166. maddesindeki hükümlerle devam etmiştir. Ekonomik, sosyal ve kültürel kalkınmanın planlı olması günümüzde halen anayasal bir gerekliliktir. Temmuz 2019 itibariyle On Birinci Kalkınma Planı (2019-2023) yürürlüktedir. 
Kalkınma planları kapsadıkları dönemler bakımından yıllık programlar (planlar), beş yıllık planlar ve perspektif planlar olmak üzere üçlü bir yapıya sahiptir (Güven, 1995: 38). Kalkınma planlarında, genelde, üzerinde önemle durulan temel makro amaçlar; büyümenin (milli gelir artışının) hızlandırılması, işsizliğin önlenmesi, bölgeler ve toplum katmanları arasındaki gelir farklılıklarının azaltılması, yapısal değişikliklerin sağlanması ve döviz tutumunun geliştirilmesi şeklinde özetlenebilmektedir. Dolayısıyla tüm sektörlerin bu amaçlara uygun bir biçimde yönlendirilmesi gerekmektedir (Geray, 1998: 5).

Kalkınma planlarında ülke genelini kapsayan tüm ekonomik sektörlere ilişkin politikalar yer almaktadır (Geray, 1986: 6). Ormancılık sektörü de sınırlı olan orman kaynakları ile toplumun bu kaynaklara yönelik talepleri arasındaki dengesizliği en rasyonel yöntemlerle çözmeye çalıştığı için aslında başlı başına ekonomik bir faaliyettir (Gümüş, 2004: 32). 14 Ekim 1960 tarihinde Tarım Bakanlığı tarafından ülke ormancılık sektörüne ilişkin etkinliklerin ve politikaların planlanmasına başlanmıştır (Çağlar, 1979: 377). Bu kapsamda Türkiye'nin planlı döneme girdiği 1963 yılından bu yana çıkartılmış bulunan kalkınma planlarında da ormancılık politikası amaçlarına, ilkelerine ve tedbirlerine yer verilmiştir (Özdönmez vd., 1996: 101).

Ormancılık; toprağı ve toprak verimliliğini koruyarak, rekreasyonel alanlar sunarak, su döngüsüne, insan sağlığına, karbon döngüsüne ve iklimin düzenlenmesine olumlu katkılar yaparak tüm toplumun parayla satın alamayacağı hizmetleri de karşılamaktadır (Akesen ve Ekizoğlu, 2010a: 9-13). Ayrıca, ulusal ekonominin önemli bir parçası olan ormancılık; tarım, hayvancılık, endüstri, ticaret, ulaştırma, turizm, madencilik ve enerji gibi ekonominin diğer sektörleriyle de karşılıklı etkileşim içindedir (Akesen ve Ekizoğlu, 2010b: 26-33). Bu etkileşimde ormancılığın diğer sektörleri geliştirme etkisi pek çok sektörden daha büyüktür. Ormancılık, pazarı olsun ya da olmasın yerine başkalarının ikame edilmesi mümkün olmayan pek çok mal ve hizmet üreterek büyümeye, yaşam kalitesini arttırmaya ve sürdürülebilir kalkınmaya destek olmaktadır (Geray, 1998: 24-25). Topluma ve diğer ekonomik sektörlere bu denli önemli ürünler ve hizmetler sunan ormancılık faaliyetlerinde 6831 sayılı Orman Kanunu'nun 40. maddesi gereği öncelikli olarak orman köylüleri ve onların kurmuş olduğu ormancillk kooperatifleri istihdam edilmektedir.

Sarp ve yüksek rakımlı yerlerde kurulmuş olmalarından dolayı orman köylerinde yaşam şartlarının güç, gelişme imkânlarının ve kamu yatırımlarının sınırlı oranda olması, orman köylüsünün ormancılık çalışmalarında öncelikli olarak istihdam edilmelerinde etkili olmaktadır (Günşen, 2012: 20). Ülke genelinde kırsal alanda yaşanan ekonomik, sosyal ve kültürel güçlükler orman köylerinde daha da yoğun bir şekilde kendini göstermektedir. Bayraktaroğlu (1968: 40) orman köylerinin kendilerine has özelliklerinden dolayı, ülkedeki kalkınma çalışmalarında bu köylere bazı konularda öncelik vermek yerine bizzat orman köylerini diğer köylerden önce ele almanın gerekli olduğunun, bunun yapılmaması halinde orman köylerinin insan gücünü kaybedeceğinin altını önemle çizmiştir. İnal (1967: 43) da orman köylerinde yürütülecek kalkınma çalışmalarının merkezi ve yerel yönetimlerin orman köylüsünün katılımını sağlayarak eşgüdüm halinde ve demokratik bir biçimde yürütülmesi gerektiğini bildirmiştir.

2000'li yıllara gelene kadar orman kaynaklarının daralmasının, tahrip olmasının ve yeteri kadar verimli ve etken olmayan ormancılık çalışmalarının ortaya çıkmasının temel nedeninin, orman köylüsünün içinde bulunduğu bu kötü sosyoekonomik koşullar olduğu dile getirilmiştir (Gümüş, 1996: 7; Geray, 1998: 13). Bu bağlamda hem ormancılığın ulusal ekonomiye katkısında azalma olmaması hem de orman alanlarının korunması için orman köylülerinin kalkındırılması gerekmiştir. Bunun önemi, gerek 1961 Anayasa’sının 131. maddesinde gerekse 1982 Anayasasının 170. maddesinde orman köylülerinin kalkındırılması konusu üzerinde durulmasından da anlaşılmaktadır (Özdönmez vd., 1989: 179-181).

1965 yılı resmi kayıtlarına göre orman köylerinde yaşayanlar ülke nüfusunun \%22'sini (DPT, 1968: 237) oluştururken kırdan kente yaşanan göçlerle birlikte bu oran 2018 yılı itibariyle \%8'e düşmüştür. 2018 y1l1 verilerine göre; 22.847 orman köyünde 6.827 .500 orman köylüsü yaşamaktadır (OGM, 2020; TÜİK, 2020). Orman köylerinin nüfusu her ne kadar azalmış olsa da orman köylülerinin varlığı önemini hala sürdürmektedir. Çünkü ormanlardan sağlanan ürün ve hizmetlerin üretiminde ağırlıklı olarak istihdam edilenler yine orman köylüleridir. Emek yoğun gerçekleştirilen ve iş sağlığı ve güvenliği açısından yüksek riskli işlerden biri olan ormancılık etkinliklerinde orman köylüsünün tecrübesi göz ardı edilemez. Ancak, ormanla iç içe yaşayan hatta artık orman ekosisteminin bir parçası olarak görülen orman köylüleri ne yazık ki halen ülke genelinde kişi başına düşen gelirin en düşük olduğu kesimi oluşturmaktadır (TUOP, 2004; Atmiş vd., 2010: 51). Koç Konu (2014:169) ülkelerin ekonomik kalkınma süreçlerinde başarılı olabilmeleri için fiziki sermayenin yanı sıra beşerî sermayenin de gelişmesi gerektiğini ifade etmektedir. İşte bu noktada orman köylüsünün ülke kalkınmasına olumlu katkısının arttırılabilmesi için; bilgi, beceri ve tecrübesinin geliştirilmesi gerekmektedir.

Orman köylüsünü kalkındırmak için geçmişten günümüze birçok politika oluşturulmuş ve yasal düzenleme 
yapılmıştır. Bu politikaları ülke kalkınma planlarında makro ölçekte görmek mümkündür. Ancak ülke kalkınma planlarındaki orman köylüsüne ilişkin hedeflerin plandan plana hangi şekilde değiştiği pek bilinmemektedir. Bu çalışmanın amacı, yaklaşık altmış yıllık bir süreyi içeren planlı dönemde, orman köylüsüne ilişkin hangi sorunların ortaya konduğunu ve hangi ölçülerde çözümler getirildiğini saptayarak bir değerlendirme yapmaktır. Böylelikle ülke kalkınma planlarının her birinde orman köylüsüyle ilgili politikalara ne derecede yer verildiği ortaya konulmuş ve ilk kalkınma planından günümüze kadar geçen sürede yürürlüğe girmiş, uygulanmış ve uygulanmaya devam eden kalkınma planlarında orman köylüleriyle ilgili politikalardaki değişiminin analiz edilmesine çalışılmıştır.

\section{Materyal ve Metot}

\subsection{Materyal}

Farklı sektörlere ait politikaların analizinde sıklıkla kullanılan materyallerden birisi de ülke kalkınma planlarıdır (Türker vd., 2000: 307; Alagöz ve Yapar, 2003: 439; Takım, 2011: 154; Küçüker, 2012: 9; Büyükşalvarc1 vd., 2016: 186). Bu çalışmanın da ana materyalini 1963 ile 2019 yılları arasında çıkartılan ve uygulanan kalkınma planları oluşturmaktadır (Tablo 1). Türkiye'de planlı döneme 1963 ile 1967 yılları arasını kapsayan Birinci Beş Yıl Kalkınma Planı ile geçilmiştir. Planlardan sadece Dokuzuncu Kalkınma Planı yedi yıllık dönemi kapsamaktadır. 2019-2023 yılları arasındaki dönemini kapsayacak şekilde hazırlanan On Birinci Kalkınma Planı Temmuz 2019'da yürürlüğe girmiştir.

Tablo 1. Kalkınma planları ve dönemleri.

\begin{tabular}{ll}
\hline Planın Adı & Dönemi \\
\hline Birinci Beş Yıl Kalkınma Planı & $1963-1967$ \\
İkinci Beş Yıllık Kalkınma Planı & $1968-1972$ \\
Üçüncü Beş Yıllık Kalkınma Planı & $1973-1977$ \\
Dördüncü Beş Yıllık Kalkınma Planı & $1979-1983$ \\
Beşinci Beş Yıllık Kalkınma Planı & $1985-1989$ \\
Altıncı Beş Yıllık Kalkınma Planı & $1990-1994$ \\
Yedinci Beş Yıllık Kalkınma Planı & $1996-2000$ \\
Uzun Vadeli Strateji ve Sekizinci Beş Yıllık Kalkınma Planı & $2001-2005$ \\
Dokuzuncu Kalkınma Planı & $2007-2013$ \\
Onuncu Kalkınma Planı & $2014-2018$ \\
On Birinci Kalkınma Planı & $2019-2023$ \\
\hline
\end{tabular}

\subsection{Metot}

Çalışma için öncelikle orman köyleri, orman köylüsü ve kalkınma planlarıyla ilgili kaynak taraması yapılmıştır. Çalışmanın temel materyalini oluşturan kalkınma planlarına Türkiye Cumhuriyeti Cumhurbaşkanlığı Strateji ve Bütçe Başkanlığı resmi web sayfasından ulaşılmıştır (SBB, 2019).

Elde edilen planlar; orman köyleri, orman köylüsü, kırsal kalkınma, kooperatifleşme vb. konular bakımından incelenmiştir. Kalkınma planlarının incelenme sürecinde yapılan çalışmalar, literatürde belgesel tarama olarak adlandırılmaktadır (Bowen, 2009: 28). İncelemelerde orman köylüsü ve kalkındırılmalarıyla ilişkili olabilecek 12 sözcük ve kavram belirlenmiştir (Tablo 2). Bunların belirlenmesinde orman köylüleriyle ilgili şimdiye kadar yapılan araştırmalardan yararlanılmıştır. Bu sözcük ve kavramların planlarda ne kadar sıklıkla kullanıldıkları içerik analiziyle ortaya konmuştur. Bunun için her bir planda bulunan sözcük ve kavramlar teker teker sayılmış ve Tablo 2 oluşturulmuştur. Ayrıca planlar arasında karşılaştırmalar da yapılmıştır. İçerik analizinin temel amacı, sayıca fazla olan metin yığınında, araştırılacak metinlerin içeriklerinin her yanıyla ve tüm boyutlarıyla ilgilenmekten ziyade özellikle ve öncelikle araştırma sorusu açısından önem arz eden ortak bilgileri tespit etmek ve değerlendirmektir (Türkdoğan ve Gökçe, 2012: 320). İçerik analizi politika araştırmalarında sıklıkla kullanıldığı (Gül, 2015: 23) gibi ormancılık politikalarıyla ilgili araştırmalarda da kullanılmaktadır (Atmiş ve Günşen, 2011: 193; Atmiş ve Günşen, 2016: 590; Günşen ve Atmiş, 2017: 209; Yurdakul Erol ve Y1ldırım, 2017: 2; Yurdakul Erol, 2018: 320). İçerik analizinden sonra her bir kalkınma planı orman köylerini ve orman köylüsünü ele alışları bakımından değerlendirilmiş, planlarda oluşturulan politikaların ve konulan hedeflerin gerçekleştirilip gerçekleştirilmediği bir sonraki planın değerlendirilmesinin başında yapılmıştır. Ayrıca planlarda orman 
köylüsünün kalkındırılması için koyulan hedefler konuyla ilgili yapılan diğer bilimsel çalışmalarla tartışılarak analiz edilmiştir.

\section{Bulgular ve Tartışma}

\subsection{Kavramsal Değerlendirme}

Tüm planlar göz önünde bulundurulduğunda bu planlarda en fazla “orman” sözcüğünün (891) kullanıldığ1 görülmektedir (Tablo 2). Bu sözcük, planlar arasında en fazla üçüncü kalkınma planında (1973-1977) kullanılmıştır (192). Daha sonraki planlarda ise bu sözcüğün kullanılma sıklığı dalgalı bir seyir gösterse de düşmüştür. Türkiye'de orman köylüsü, ormanın her zaman bir parçası olarak görülmüştür. Bundan dolayı planlarda "orman” sözcüğüne değinilirken "orman köyü” ya da "orman köylüsü” kavramları ne kadar yer alıyor bilinmesi gerekmektedir. Planlarda "orman” sözcüğünün kullanım sıklığına karşın "orman köyü” ve "orman köylüsü" kavramları daha az yer alabilmiştir. Toplamda “orman köyü” kavramı 25, "orman köylüsü” ise 29 defa kullanılmıştır. Planlar ayrı ayrı değerlendirildiğinde ise “orman köyü” en çok ikinci planda (1968-1972) kullanılmıştır (18). Orman köyü kavramına birinci (1963-1967), beşinci (1985-1989), altıncı (1990-1994), yedinci (1996-2000), dokuzuncu (2007-2013) ve on birinci (2019-2023) planlarda ise hiç değinilmemiştir. "Orman köylüsü” kavramına en sık dördüncü planda (1979-1983) değinilmiştir (11). Bu kavrama birinci, beşinci, dokuzuncu ve onuncu planda hiç değinilmemiștir. Bu kavramların kalkınma planları içindeki yeri bu çalıșmanın “Orman Köylüsüyle İlgili Hükümler” ve “Orman Köylüsüne İlişkin Hedeflerdeki Değişim” başlıkları altında ayrıntılı olarak yapılmıştır.

Planların tümü değerlendirildiğinde "orman” sözcüğünden sonra ikinci sırada en çok kullanılan kavram "kırsal kalkınma"dır (63). Bunu "sürdürülebilir kalkınma" (38) takip etmektedir. İlk kez beşinci planda (1985-1989) değinilen "kırsal kalkınma" kavramına en sık sekizinci planda (17) yer verilmiştir. "Köy kalkınması"na sadece birinci, üçüncü ve dördüncü planda, "sürdürülebilir kalkınma"ya ise yedinci, dokuzuncu, onuncu ve on birinci planda değinilmiştir (Tablo 2).

Planlarda kırsal kalkınmada önemli bir araç olarak görülen kooperatiflerden (Atmiş vd., 2009: 2) neredeyse hiç bahsedilmemiştir. Orman köylerinde bulunan tarımsal kalkınma kooperatiflerine; "Ormancılık kooperatifi" olarak üçüncü planda bir defa ve dördüncü planda iki defa, "Tarımsal kalkınma kooperatifi" olarak ise ikinci planda bir, üçüncü ve dördüncü planlarda ise ikişer defa değinilmiştir (Tablo 2). Yine planlarda kırsal kalkınmayla ilişkili olan ve direkt olarak orman köylüsünü kalkındırmayı amaçlayan sosyal ormancılık, tarımsal ormancılık ve toplum ormancılığı kavramlarına yok denecek kadar az değinilmiştir. Sürdürülebilir orman yönetiminden ise dokuzuncu ve on birinci planda (2007-2013) toplam üç defa bahsedilmiştir.

Tablo 2. Kalkınma planlarında seçilen sözcük ve kavramların sıklığı.

\begin{tabular}{|c|c|c|c|c|c|c|c|c|c|c|c|c|}
\hline Sözcük ve Kavramlar & $\begin{array}{c}\text { I. } \\
\text { Plan } \\
1963 \\
1967\end{array}$ & $\begin{array}{c}\text { II. } \\
\text { Plan } \\
1968 \\
1972\end{array}$ & $\begin{array}{c}\text { III. } \\
\text { Plan } \\
1973 \\
1977\end{array}$ & $\begin{array}{c}\text { IV. } \\
\text { Plan } \\
1979 \\
1983\end{array}$ & $\begin{array}{c}\text { V. } \\
\text { Plan } \\
1985 \\
1989\end{array}$ & $\begin{array}{c}\text { VI. } \\
\text { Plan } \\
1990 \\
1994\end{array}$ & $\begin{array}{c}\text { VII. } \\
\text { Plan } \\
1996 \\
2000\end{array}$ & $\begin{array}{l}\text { VIII. } \\
\text { Plan } \\
2001 \\
2005\end{array}$ & $\begin{array}{c}\text { IX. } \\
\text { Plan } \\
2007 \\
2013\end{array}$ & $\begin{array}{c}\text { X. } \\
\text { Plan } \\
2014 \\
2018\end{array}$ & $\begin{array}{c}\text { XI. } \\
\text { Plan } \\
2019 \\
2023\end{array}$ & Toplam \\
\hline Orman & 93 & 170 & 192 & 157 & 21 & 81 & 63 & 62 & 13 & 22 & 17 & 891 \\
\hline Orman köyü & 0 & 18 & 3 & 2 & 0 & 0 & 0 & 1 & 0 & 1 & 0 & 25 \\
\hline Orman köylüsü & 0 & 2 & 2 & 11 & 0 & 3 & 5 & 5 & 0 & 0 & 1 & 29 \\
\hline $\begin{array}{l}\text { Orman/Ormancılık } \\
\text { kooperatifi }\end{array}$ & 0 & 0 & 1 & 2 & 0 & 0 & 0 & 0 & 0 & 0 & 0 & 3 \\
\hline $\begin{array}{l}\text { Tarimsal kalk. } \\
\text { kooperatifi / Köy kalk. } \\
\text { kooperatifi }\end{array}$ & 0 & 1 & 2 & 2 & 0 & 0 & 0 & 0 & 0 & 0 & 0 & 5 \\
\hline Sosyal ormancılık & 0 & 0 & 0 & 0 & 0 & 1 & 0 & 2 & 0 & 0 & 0 & 3 \\
\hline Toplum ormancılığı & 0 & 0 & 0 & 0 & 0 & 0 & 1 & 0 & 0 & 0 & 0 & 1 \\
\hline Tarımsal ormancılık & 0 & 0 & 0 & 0 & 0 & 1 & 0 & 1 & 1 & 0 & 0 & 3 \\
\hline Kırsal kalkınma & 0 & 0 & 0 & 0 & 4 & 1 & 1 & 17 & 10 & 15 & 15 & 63 \\
\hline Köy kalkınması & 3 & 0 & 8 & 4 & 0 & 0 & 0 & 0 & 0 & 0 & 0 & 15 \\
\hline $\begin{array}{l}\text { Sürdürülebilir } \\
\text { kalkınma }\end{array}$ & 0 & 0 & 0 & 0 & 0 & 0 & 14 & 0 & 1 & 12 & 11 & 38 \\
\hline $\begin{array}{l}\text { Sürdürülebilir orman } \\
\text { yönetimi }\end{array}$ & 0 & 0 & 0 & 0 & 0 & 0 & 0 & 0 & 2 & 0 & 1 & 3 \\
\hline Toplam & 96 & 191 & 208 & 178 & 25 & 87 & 84 & 88 & 27 & 50 & 45 & 1079 \\
\hline Plan sayfa sayısı & 535 & 665 & 1077 & 699 & 221 & 375 & 319 & 254 & 101 & 212 & 209 & 4667 \\
\hline
\end{tabular}




\subsection{Orman Köylüsüyle Illgili Hükümler}

Bu bölümde her bir kalkınma planında orman köylüsüyle ilgili tespitler ve politikalar ayrı ayrı incelenerek değerlendirilmiştir.

\subsubsection{Birinci Beş Yıl Kalkınma Planı (1963-1967)}

Birinci Beş Yıl Kalkınma Planı (1963-1967), bir perspektif (15 yıl süreli) planın ilk safhası olarak hazırlanmıştır. Bu süreçte ulaşılmak istenen sosyal ve ekonomik hedeflerle, harekete geçirilmesi gereken kaynaklar 15 ylllık bir perspektif açısından ele alınmışıır. Bu nedenle, planın sosyal hedeflerinin ve bunlar arasındaki önceliklerin saptanmasında ve çeşitli sektörlerin gelişme programlarının hazırlanmasında 15 yılın sonunda beklenen sonuçlara göre hareket edilmiştir (DPT, 1963: 33).

Planın, ülke genelinde tasarrufu artırmak, yatırımları toplum yararına, gerektirdiği önceliklerle yöneltmek, ekonomik, sosyal ve kültürel kalkınmayı demokratik yollarla gerçekleştirmek amacıyla hazırlandığı belirtilmektedir. Planda kalkınma amaçlarını yerine getirebilmek için gerekli en önemli ilkelerin; ekonomik kalkınma ile geliştirilen kaynakların yurt refahının artırılmasında kullanılarak halkın yeterli bir yaşama seviyesine ulaştırılması, sosyal güvenlik, adil bir gelir dağılımı ve ülke genelinde bir firsat eşitliğinin sağlanması olduğu ifade edilmektedir (DPT, 1963: 3 - 47). Güven'e göre (1995: 40) plan bu özellikleriyle karma ekonomi düzenini esas almaktadır ve özel sektör için özendirici kamu için ise buyurucu niteliği birbiriyle dengeli ve bütünlük göstermektedir.

Plan döneminde, deneme amaçlı halk-orman ilişkilerinin düzenlenmesi açısından orman içinde yaşayan halkın bulundukları yerlerde kooperatif̧̧iliğin de teşvik edilmesiyle birlikte kalkındırılması çalışmalarına başlanacağı, sonuçlara göre de köy kalkınması çalışmalarına devam edileceğinden bahsedilmektedir (DPT, 1963: 184). Burada "halk-orman arasındaki ilişkinin düzenlenmesi" ifadesinde "halk" olarak toplumun tamamı değil sadece orman köylüsü ele alınmıştır. Çünkü orman köylüsünün sosyal ve ekonomik açıdan içinde bulunduğu zor şartlar, onların temel ihtiyaçlarını karşılayabilmek için ister istemez ormanlar üzerinde baskı kurmalarına neden olmuştur. Hem köylerin bulunduğu olumsuz şartları iyileştirmek hem de ormanlar üzerindeki baskıyı azaltmak için orman köylerinin kalkındırılmaları hedeflenmiştir. Dikkat çeken bir diğer nokta ise, 1960'lı yıllarda özellikle yurtdışına iş̧i gönderilmesinde köylülere kolaylık sağlanması maksadıyla devlet desteğiyle kurdurulan kooperatiflerin (Günşen, 2006: 2) ülke kalkınmasında bir araç olarak da görülmesidir.

Diğer taraftan orman ürünlerinin üretiminin arttırılmasıyla birlikte ihtiyaç duyulacak orman yolları yapımı, üretim ve taşıma işlerinde yerel iş gücünün değerlendirileceği ifade edilmektedir (DPT, 1963: 183). Bu ifade aslında 1956 yılında yayımlanan Orman Kanunu ile ormancılık mevzuatına girmiştir. 08.09.1956 tarihli ve 6831 sayılı Orman Kanunu'nun 40. maddesinde: "Devlet ormanlarında kesme, taşıma, toplama, imal, bakım, imar, ağaçlama, yol yapma gibi, orman işleri iş yerindeki veya civarındaki orman işlerinde çalışan köylülere veya tercihen aralarında köy orman kooperatifi kuranlara gördürülür...” denmektedir (Rega, 1956: 15532).

\subsubsection{Ikinci Beş Yıllık Kalkınma Planı (1968-1972)}

Birinci kalkınma planı göz önünde bulundurularak yapılan durum tespitinde, orman köylerine ulaşımın güç ve ev yerleşimlerinin dağınık olmasının imkânlardan yararlanmalarını kısıtladığı, sınırlı gelişme gücüne sahip oldukları için bu köylerde yaşam şartlarının güç ve kalkınma imkânlarının kıt olduğu belirtilerek orman köylerinin kalkındırılmasında belli bir başarının sağlanamadığı ifade edilmektedir (DPT, 1968: 246). Bu değerlendirmenin yanında birinci planda belirtilen orman köylerinde kooperatifçiliğin teşvik edilmesinde ve ormancilıkla ilgili işlerde orman köylüsünün istihdamında nelerin gerçekleştirildiğine ise değinilmemiştir. Çağlar (1979: 382) da birinci planla ilgili yaptığı değerlendirmelerinde, plan dönemi boyunca uygulanacak ormancılık politikası için saptanan ilkelerin büyük ölçüde kâğı üzerinde kaldığını, orman köylüsünün kalkındırılmasıyla ilgili öngörülerin ise neredeyse hiç gerçekleşmediğini söylemektedir.

İkinci kalkınma planında istihdam yaratmak için oluşturulan politikaların uygulanmasında "öncelikle orman köyleri gibi işsizlik sorununun yoğun olarak yaşandığı çevreler üzerinde durulacă̆ı" önemle belirtilmektedir (DPT, 1968: 134).

Orman köyü ve orman köylüsü sayısına ilk defa bu planda değinilmiştir. Buna göre, ülke genelindeki 65.277 köyden 5.020'si orman içinde 8.250'si ise orman kenarında kurulmuştur. Orman içi köylerde 2.400 .000 ve orman kenarındaki köylerde ise 4.500.000 orman köylüsü bulunmaktadır (DPT, 1968: 237). Ülkedeki köylerin \%20'sini oluşturan 13.270 orman köyünde 6.900 .000 orman köylüsü yaşamaktadır. 1965 yılı ülke nüfusuna göre, orman 
köylerinde yaşayan nüfus ülke nüfusunun \%22'sini, kırsal kesimde yaşayan nüfusun ise \%33'ünü oluşturmaktadır. Planda, 1950 yılından itibaren köylerde yaşayan nüfusun, toplam nüfusa oranında düşüş görüldüğü ancak köylerdeki nüfusun kalkınma çalışmalarını olumsuz yönde etkileyecek bir hızla arttığı ifade edilmektedir. Ayrıca, köylerdeki nüfusun hızlı artmasının orman, toprak, su ve mera gibi kaynakları tahrip ettiğine ve şehrin çekimine uyarak daha iyi yaşama şartlarına sahip olmak isteyen köylünün de şehre göç ettiğine değinilmektedir (DPT, 1968: 237).

Planda köy ve köylü sorunlarıyla ilgili durum tespitinde, yerleşme yerlerinin özel sorunlar getirdiği köylerin başında orman köylerinin geldiğinin altı özellikle çizilmektedir. Planda 5.508 orman köyünde yapılan bir araştırmaya göre, bu köylerin \%62'sinin bulundukları yerlerde kalkındırılabileceği \% 38'inin ise bulundukları yerlerde kalkındırılmalarının mümkün olmadı̆̆ı ifade edilmektedir (DPT, 1968: 245). Orman köylerinin kalkındırılabilmeleriyle ilgili bu araştırmanın 6831 sayılı Orman Kanunu'nun 13. Maddesine göre yapıldığı anlaşılmaktadır (Rega, 1956: 15530). 13. madde kısaca orman köylerini bulundukları yerde kalkındırılabilen ve bulundukları yerde kalkındırılması mümkün olmayan köyler olarak iki kategoriye ayırmaktadır.

6831 sayılı Orman Kanunu'nun 13. maddesinin a bendine göre bulunduktan yerlerde kalkındırılabilecek orman köyleri için Ziraat Bankasında tesis edilecek özel bir fona yılda 50 milyon liradan az olmamak şartı ile Hazineden kaynak sağlanması öngörülmektedir (Rega, 1956: 15530). Bu fona 1957 y1lından 1966 ya kadar toplam olarak ancak 11,5 milyon liralık ödenek konulabildiği planda belirtilmektedir. Orman köylerinin kalkındırılması için fonda biriktirilmesi gereken paranın neredeyse hiç toplanamadığı açıkça görülmektedir. Bunun nedeni olarak bankacılık mevzuatındaki güçlükler ve fonların nasıl kullanılabileceğinin belirlenememiş olması olarak ifade edilmektedir. Planda orman köylerinin kalkındırılmasıyla ilgili yaşanan çeşitli güçlükler neticesinde orman köylüsünün başta ormanlar olmak üzere doğal varlıklar üzerinde olumsuz etkisinin arttığı ve buna bağlı olarak bölgelerin insan barındırma gücü ve ekonomi içindeki yerinin azaldığına değinilmektedir (DPT, 1968: 246).

Planda yerleşim yeri sorunlarının çözümüne yönelik uygulanacak politikalar içinde orman köylerine de değinilmektedir. Bunlar (DPT, 1968: 249);

$>$ “Toplam köy nüfusunun yaklaşık olarak yüzde 30’unu barındıran orman köylerini kalkındırmak için orman işletme, orman ürünlerinin nakli, orman 1slah ve tesis çalışmaları ile su kontrolü, toprak koruması ve orman yolu yapımı gibi işlerde orman köylülerinin geniş oranda çalıştırılmaları ve bu konuda teşkilatlanmaları sağlanacaktır. Hayvan ırkı ve mera 1slahı çalışmaları ile yem bitkileri yetiştirme çalışmalarında orman köylerine öncelik verilecektir. Orman köylerindeki düşük verimli ve orman için zararlı olan hayvanların yerine, yüksek verimli ve orman için zararsız hayvanların ikame edilmesi çabaları hızlandırılacaktır."

$>$ "Ekonomik değeri olan el ve ev sanatları ile orman artıklarını değerlendirecek tipteki el ve ev sanatları ürünlerinin piyasayla ilişkileri de dikkate alınarak, desteklenecek ve köylünün bu konuda teşkilatlanması sağlanacaktır.”

$>$ "Orman köylerinin kalkındırılması için orman köylerine verilen krediler etkili ve gerçekçi bir düzene bağlanacaktır. Tarımda çalışan nüfusu tarım dışı sektörlere aktarmak amacıyla düzenlenecek mesleğe yönelme eğitimi programlarına orman köylerinde öncelik verilecektir."

$>$ "Orman içinde yaşayan halkın bulundukları yerlerde kalkındırılmaları için özellikle kooperatifleşme teşvik edilecektir."

Ormanların işletilmesi ve korunması açısından orman-halk ilişkilerinin düzenlenmesinin planda ormancılık ilkesi olarak yer aldığı görülmektedir (DPT, 1968: 342). Planda, ülke ormancılığının önde gelen sorunlarından biri olarak görülen orman-halk ilişkisinin bozuk olmasının, kırsal nüfusun ormanlar üzerinde yarattığı baskıdan ve orman sınırlarının kesin olarak belirlenememiş (kadastro çalışmalarının tamamlanamamış) olmasından kaynaklandığı ifade edilmektedir. Orman içindeki köylerde yaşayanların içinde bulundukları olumsuz şartlardan dolayı ormanlara yönelerek arazi edinme, izinsiz kesim ve düzensiz otlatmalar ile ormanlar üzerinde bask1 oluşturduğu ve bunun da ormanların bozulmasına neden olduğuna değinilmektedir (DPT, 1968: 342).

Ormancılıkta politika tedbirlerinde; ağaçlandırma, imar, toprak muhafazası gibi önemli yatırımların gerçekleştirilmesini etkileyen orman kadastrosu çalışmalarının öncelikle orman-halk ilişkilerinin düzenlenmesine en çok ihtiyaç duyulan yerlerde yapılacağına, bu orman sınırlandırma çalışmalarında ve ormandan faydalanmada orman varlığının korunmasının yanı sıra orman-halk ilişkilerinin de gözetileceğine değinilmektedir (DPT, 1968: 348).

\subsection{3 Üçüncü Beş Yılık Kalkınma Planı (1973-1977)}

Üçüncü kalkınma planı önceden belirlendiği gibi 15 yıllık perspektif planın son dilimini oluşturmak yerine 22 yıllık bir dönemi kapsayan Yeni Perspektif 'in ilk kısmını oluşturmuştur (Güven, 1995: 19). Avrupa Birliği'ne 
katılma süreci sektörlerin 22 yıllık dönemde belirli yönde geliştirilmesini zorunlu kılmıştır. Buna bağlı olarak ormancılık gibi hammadde dengesi yönünden uzun dönemli planların hazırlanmasına ihtiyaç duyulan sektörlerde ana plan hazırlanması yoluna gidilmiştir (DPT, 1972: 203). Böylelikle 1973-1995 yılları arasında kalan dönemi kapsayan ilk Ormancılık Ana Planı hazırlanmış ve uygulamaya konmuştur. Ormancılık Ana Planında ülke kalkınma planında yer alan ormancılık politikası amaçlarına yönelik ilke, hedef ve tedbirler yer almıştır. Ana planda özellikle orman içi ve kenarında yaşayan orman köylüsünün hayat standartlarının ve gelir seviyelerinin yükseltilmesine katkıda bulunmak için getirilen çeşitli tedbirlerden de bahsedilmektedir (Anonim, 1976: 1). Ancak bu çalışmada sadece kalkınma planlarının değerlendirilmesi yapıldığı için ilk ormancılık ana planı ayrıntılı olarak ele alınmamıştır.

Kalkınma planında ormancılıkla ilgili uzun dönem gelişme hedeflerinde (1972-1995) orman köylüsüyle ilgili olarak; "orman sınırlandırma çalışmalarının en kısa sürede tamamlanarak, orman-halk ilişkilerinin düzenlenmesi ve rasyonel arazi kullanımı olanaklarının sağlanması yolu ile ormanların yapısının iyileştirilmesi sağlanacaktır" denmektedir (DPT, 1972: 262). Aslında buradan orman köylerinde yaşayan insanların kalkındırılması çalışmalarının başarılı olamadığı ve bu nedenle ormanlar üzerindeki baskıların da halen devam ettiği yönünde bir sonuç çıkmaktadır.

Planda, orman köylüsüne ve diğer hak sahiplerine 6831 sayılı Orman Kanunu'na göre ayni olarak ucuz tarife ile verilen hakların (tomruk veya odun) hammadde kullanımını rasyonelleştirmek ve sanayiye verilecek hammaddenin maliyetini ucuzlatmak için işlenmiş ürün olarak ya da nakden verilmesinin olanaklarının geliştirileceği ifade edilmektedir. Diğer taraftan orman-köylü ilişkilerinin düzenlenmesinde tüm kuruluşların birlikte çalışacağı ve bunların da ana planlara bağlanacağı konusu vurgulanmaktadır (DPT, 1972: 268).

Kırsal alanda yaşayan nüfusun yaklaşık \%30’unu barındıran orman köylerinin özel yerleşim sorunları olduğuna değinilerek, bu sorunların orman - köylü ilişkilerinde olduğu kadar vatandaş-hizmet ilişkileri açısından da sorunlar yarattı̆̆ ifade edilmektedir (DPT, 1972: 845).

Planda köy ve köylü sorunlarının çözümünde tarım, ormancılık, hayvancılık ve su ürünlerinin üretildikleri yerlerde değerlendirilmesi için ev ve el sanatlarının destekleneceği, kredi ve pazarlanmaları için de kooperatiflerden yararlanılacağı ifade edilmektedir. Orman köylerindeki kalkındırma çalışmalarında köyün tamamının gözetileceğinin esas olacağı belirtilmektedir (DPT, 1972: 865).

\subsubsection{Dördüncü Beş Yıllık Kalkınma Planı (1979-1983)}

Dördüncü planda, ormancılık yatırımlarının gerçekleşmesinin üçüncü planda koyulan hedeflerin gerisinde kaldığ1 tespit edilmiştir (DPT, 1979: 331). Planda orman-insan ilişkilerinin düzenlenmesi, kişilerin ormana ve ağaçlandırma alanlarına olumsuz etkilerinin azaltılması ve bazı orman köylüsünün mülkiyet haklarının korunması amacına yönelik olarak 2.827.000 hektarlık alanda kadastro çalışması yapılmış olduğu belirtilmiştir (DPT, 1979: 367). Planda bir durum tespiti yapılarak 1960'lı yıllarda kurulmaya başlanan orman köy kalkınma kooperatifleri sayısının 1976 yılında 595'e ve ortak sayısının da 3000'e ulaştı̆̆ 1 belirtilmektedir (DPT, 1979: 130). Ancak bir kooperatifin kurulabilmesi için en az yedi ortağa ihtiyaç olduğu düşünüldüğünde kurulan kooperatif sayısı ile ortak sayısı arasında bir uyuşmazlık olduğu görülmektedir. Ayrıca üçüncü plan döneminde (1973-1977) orman köylüsünün sosyoekonomik durumunu iyileştirmek için 1007 orman köy kalkınma kooperatifi kurulmuş olduğu rapor edilmiştir. 143 ilçenin 4.959 orman köyünü kapsayan ilçe planlarının düzenlenmiş olduğu, 52 ilçenin 1945 orman köyünde etüt- envanter çalışmalarının tamamlanmış olduğu ve 20 ilçenin 876 orman köyünde ise etütenvanter çalışmalarının devam etmekte olduğu belirtilmiştir (DPT, 1979: 369).

Planda tarımla, hayvancılıkla, balıkçılıkla ve ormancılıkla ilgili devlet desteklemeleri, yatırımları ve yardımlarının kooperatifleşmiş dar ve orta gelirli üreticilere dönük biçimde uygulanacağına değinilmektedir (DPT, 1979: 290). Ormancılık özelinde ise, orman varlığının değerlendirilmesi, orman ürünlerinin pazarlanması, taşımacılık, orman ürünleri sanayiinin kurulması ve geliştirilmesi amacıyla orman köylülerince kurulan kooperatiflerin destekleneceği (DPT, 1979: 291), orman kooperatiflerinin ormanın korunmas1, gözetimi, geliştirilmesi ve ağaçlandırılmasında, orman köyleri ile Devlet iş birliğini sağlayan araç olarak kullanılacağı ifade edilmektedir (DPT, 1979: 292).

Dördüncü planda ormancılık sektörünün hedeflerinden biri, orman köylüsünün sosyal refah düzeyini yükseltici çabalara 16.129 kırsal yerleşim merkezinde sürdürülecek etüt- proje çalışmalarıyla devam edilmesi ve eğitim kurumları ile ordunun bu faaliyetlere katkısının sağlanması olmuştur (DPT, 1979: 372). Ayrıca planda, orman işletmeciliğinde ve orman ürünlerinin değerlendirilmesinde orman köylülerince kurulan kooperatiflerin etkinliğinin artırılacağına da değinilmektedir (DPT, 1979: 373). Orman kadastrosu çalışmalarının 
tamamlanamamasından dolayı orman mülkiyetinin devlet-orman-köylü ilişkilerinde bir sorun olarak ortaya çıktığı planda vurgulanmaktadır. Orman köylüsünün yaşam düzeyini yükseltmek ve ormanların korunmasında etkinliğini artırmak için orman mülkiyeti belirsizliğinin tüm kuruluşların eşgüdüm ve iş birliği ile düzenleneceğine planda yer verilmektedir (DPT, 1979: 373).

Dördüncü planda kalkınmalarının sağlanması için köylüye yönelik bir takım politikalar geliştirilmiştir. Bu politikalardan ilki etkili bir toprak reformunun oluşturulmasıdır. Toprak reformu ile tarımdaki toprak ve gelir adaletsizliğini gidererek toplumsal adaleti sağlamak, köylüyü topraksızlıktan kurtararak toprağa ve daha yüksek gelire kavuşturmak hedeflenmiştir. Bu çerçevede devlete ait topraklardan ve orman niteliğini kaybedip kanuna göre orman sınırı dışına çıkarılan topraklardan, topraksız ve az topraklı köylülerin yararlandırılacağı belirtilmektedir (DPT, 1979: 289). Bu ifadeler daha sonra ülke gündemini uzun yıllar meşgul edecek 2/B konusunun ülke kalkınma planlarına dördüncü planla girdiğini göstermektedir.

$\mathrm{Bu}$ planda ekonomik amaçlara ulaşmak için kullanılacak araçlarda ormanlara ve orman köylüsüne de değinilmektedir. Orman köylülerinin orman ürünlerini her aşamada değerlendirme olanaklarının geliştirilmesi ve orman köylüleriyle orman işletmeleri arasında hem orman verimini hem de köylünün gelirini yükseltici bir iş birliği düzeninin kurulması birer araç olarak ele alınmıştır. Ayrıca ormanların korunmasına, geliştirilmesine ve yeni ormanlar yetiştirilmesine orman köylüsünün ve genel olarak halkın etkin biçimde katkısının özendirilmesi de bir araç olarak görülmüştür (DPT, 1979: 661). Bu konuda bir diğer araç olarak ise köykentler yoluyla kırsal alanda, tarıma, hayvancılığa ve ormancılığa dayalı sanayilerden başlanarak, sanayi yatırımlarının geliştirilmesi ve halk girişimleri ile kooperatifçiliğin bu yönde desteklenmesi olmuştur (DPT, 1979: 664). İlk Köykent uygulamaları 1978-1979 döneminde Cumhuriyet Halk Partisi’nin öncülüğünde Taşkesti (Bolu) ve Özalp (Van) ilçelerinde uygulanmıştır. Proje alanlarında Orman Bakanlığı ile Köyişleri ve Kooperatifler Bakanlığının birbirinden bağımsız çalışması koordinasyon sorunlarını beraberinde getirmiştir (Çolakoğlu, 2007: 194). Özalp’taki köy kent projesi köylünün gönüllü katılımının yeterli düzeyde sağlanamaması nedeniyle sönük kalmış ve hükümet değişikliğiyle birlikte de sona ermiştir (Yeşilbaş, 2011: 160). Köykent projesi Ordu Mesudiye'de (2000-2003 yılları arasında) olduğu gibi Türkiye'de belli dönemlerde kısmi olarak uygulanabilmiştir. Ancak hükümet değişiklikleri, konuya gereken değerin verilmemesi, ekonomik güçlüklerden dolayı yatırımların yapılamaması bir daha ele alınmamak üzere köykent projesinin gündemden kalkmasına neden olmuştur (Erdönmez, 2005: 50).

Planda toplumsal amaçlara yönelik araçlar arasında toplum kesimleri arasındaki gelir dağılımını iyileştirmek amacıyla köylünün kalkınma olanakları ve gelirinin artırılacağı da yer almaktadır. Bu konuda orman köylüsüyle ilgili olarak, orman işletmeciliğinde ve orman ürünlerinin değerlendirilmesinde orman köylülerince kurulan kooperatiflerin etkinliğinin artırılacağı ifade edilmektedir (DPT, 1979: 666).

\subsubsection{Beşinci Beş Yılık Kalkınma Planı (1985-1989)}

Planda ormancılıkla ilgili politika esasları içinde orman köylüsüyle ilgili olarak, özel ağaçlandırma çalışmaları ve köylüye yönelik diğer sosyoekonomik faaliyetlerin devletçe teşvik edileceği ifade edilmektedir (DPT, 1984: 194). Bu planda orman köylüsüne çok kısıtlı yer verildiği görülmektedir. 1980'li yıllarda küreselleşmeyle birlikte uluslararası iktisadi yapıdaki dönüşüm daha da belirginleşmiş ve Türkiye'deki kalkınma politikaları ve planlarında da yansımasını bulmuştur. Soyak ve Eroğlu (2008: 526) bu süreçte Uluslararası Para Fonu (IMF) ve Dünya Bankası'nın (WB) dayattığı politikalar yüzünden ülke kalkınma politikalarının ulusal niteliğinin kaybolduğunu dile getirmektedir. Kayıkçı da (2005: 95) 1980 sonrası uygulanan dış ticaret politikalarının tarım sektörünü diğer sektörlere göre daha geri plana attığını, oluşturulan politikalarda köylüye daha az yer verildiğini, kültürel ve toplumsal boyutun tamamen göz ardı edildiğini belirtmiştir.

\subsubsection{Altıncı Beş Yıllık Kalkınma Planı (1990-1994)}

Planda ormanların genişletilmesinin ve orman köylüsünün kalkındırılmasının teknik ve parasal tedbirlerle desteklenmesi ve özel orman kurulmasının teşvik edilmesi ormancılık ilkesi olarak belirlenmiştir (DPT, 1989: 61). Diğer ormancılık ilkeleri olarak enerji ormanları tesisi, hatıra ormanları kurulması, yeşil kuşak çalışmaları, rüzgâr perdesi ve koruyucu orman şeritleri oluşturulması planda hedeflenmektedir. Ayrıca ağaçlandırmalarda çok amaçlı türlerin kullanılması ile korunga ekimleri ve benzeri tarımsal/sosyal ormancılık faaliyetlerinin yaygınlaştırılacağı ve destekleneceği de ifade edilmektedir (DPT, 1989: 61).

Basit ve ucuz teknolojilerle çalışabilen bıçkı sanayiinin mevcut yöresel işletmeler eli ile yürütülmesi hedeflenmektedir. Bunun maliyetleri düşürürken, kalitenin artırılmasına ve orman köylüsüne ek imkânlar sağlayacağına katkısı olacağı belirtilmektedir (DPT, 1989: 131). Ancak planda bu ek imkânların neler olduğundan 
bahsedilmemektedir. Yine planda orman yolları ile orman içi ve bitişiği köy yollarının yapım ve bakımında ilgili kuruluşlar arasında etkin bir iş birliğinin sağlanacağı ifade edilmektedir (DPT, 1989: 276).

\subsubsection{Yedinci Beş Yıllık Kalkınma Planı (1996-2000)}

Orman-köylü-devlet ağında orman sınırlandırma çalışmalarının yetersizliğine çözüm getirecek kadastro faaliyetlerine yedinci plan döneminde yapılan 2,3 milyon hektarlık uygulama ile devam edildiği ve 1994 yılı sonu itibariyle 20,2 milyon hektar orman alanının \%64'ünün kadastro işlemlerinin tamamlandığı bildirilmektedir (DPT, 1995: 59).

Yedinci plana kadar kaydedilen gelişmelere rağmen orman içi köylerin sosyoekonomik durumlarının düşük olmasının ormancılık sektörünün ana sorunlarından biri olmaya devam ettiğine vurgu yapılmaktadır (DPT, 1995: 59). Plana göre orman köylüsünün sosyal refah seviyesini yükseltmek, ormanları daha etkin korumak ve geliştirmek hedefi doğrultusunda özel orman kurma ile "sosyal ve toplum ormancılı̆̆ı" gibi faaliyetlerin destekleneceği ifade edilmektedir. Bu çalışmalar sürdürülürken de devlet ormanlarının ekosistem bütünlüğünün ve kamu haklarının korunmasına özen gösterileceği bildirilmektedir (DPT, 1995: 62).

Var olan aksaklıkları gidermek amacıyla 2924 sayılı Orman Köylülerinin Kalkınmalarının Desteklenmesi Hakkında Kanunda gerekli değişikliklerin yapılacağına da planda yer verilmiştir (DPT, 1995: 187). Bu değişiklik ile ilgili teklif yasalaştığında, orman vasfını yitirmiş ve kentleşmiş olan alanların satılmak suretiyle, devletin hem arsadan hem de bundan sonraki alım satımdan tapu harçları yoluyla yararlanmasının sağlanacağı, bu durumda Hazinenin sadece İstanbul'da 150 milyon metrekare alandan önemli ölçüde yarar sağlamasının mümkün olacağı bildirilmektedir (DPT, 1995: 188). Dördüncü kalkınma planında toprak reformu ile kırsal alanların kalkındırılmasına destek olmak için köylünün orman vasfını kaybetmiş alanlardan yararlandırılması hedeflenirken, yedinci kalkınma planında, orman köylüsünün kalkındırılmasıyla ilgili birçok sorun da devam ederken, orman vasfını kaybetmiş 2/B alanlarının satılarak devletin para kazanması amaçlanmıştır. Nitekim 2002 yılında iktidara gelen yeni hükümet de bu alanlara ekonomik bir gelir kaynağı gözüyle yaklaşmış, 2/B alanlarının orman köylüsü dışındaki kesimlere de satılması gündeme getirilerek 25 milyar dolarlık bir gelir beklentisi oluşturulmuştur. Daha sonra 2012 yılında çıkartılan 6292 sayılı Orman Köylerinin Kalkındırılmalarının Desteklenmesi ve Hazine Adına Orman Sınırları Dışına Çıkarılan Yerlerin Değerlendirilmesi ile Hazineye Ait Tarım Arazilerinin Satışı Hakkında Kanun'la, Anayasaya aykırı olmasına rağmen, 2/B alanları işgalcilerine öncelik verecek şekilde satılmaya başlanmıştır (Erdönmez, 2013: 316; Çağlar, 2015: 50; Günşen ve Atmiş, 2019: 188).

\subsubsection{Uzun Vadeli Strateji ve Sekizinci Beş Yılık Kalkınma Planı (2001-2005)}

Orman içi yerleşimlerin düzenlenmesi, ormanların korunması ve geliştirilmesine yönelik olarak, orman-köylü ilişkilerini düzenleyen uygulamalarda, devletin sağlayacağı destek ve etkin yönlendirme ihtiyacının devam ettiği belirtilmektedir (DPT, 2000: 71). Planda, ülkedeki yoksul nüfusun \%73,5'ini tarım ve ormancılıkla uğraşanların oluşturduğu tespit edilmiştir (DPT, 2000: 101). Tarım ve ormancılıkla uğraşanların ülkedeki en büyük yoksul grubu oluşturduğu açıkça görülmektedir. Bir önceki planlı dönemde tarım ve orman işçilerini kapsayacak ayrı bir Tarım İş Kanunu'nun çıkartılamadı̆̆ı ifade edilmektedir (DPT, 2000: 105).

Ormancılık başlığında amaçlar, ilkeler ve politikalarda: içinde orman köylüsünün sosyoekonomik durumunun iyileştirilmesinin de olduğu amaçlar için plan döneminde 300.000 hektar ağaçlandırma, 175.000 hektar toprak muhafaza ve 30.000 hektar mera ıslahı çalışması yapılması hedeflenmiştir. Bu çalışmaların orman bakım çalışmalarının aksatılmadan, özellikle hızlı büyüyen türlere ağırlık verilerek yapılacağ ifade edilmektedir (DPT, 2000: 141).

Planda, orman köylüsünün kalkındırılması amacıyla meşe, akasya, fıstık çamı ve benzeri çok yönlü yarar sağlayan türleri içeren sosyal ve tarımsal ormancılık faaliyetleri ile tıbbi, aromatik ve süs bitkileri üretiminin geliştirileceği, enerji ormanları tesisinin yaygınlaştırılacağı ifade edilmektedir. Ayrıca gerçek ve tüzel kişilerin özel orman kurma etkinliklerinin destekleneceği söylenmektedir (DPT, 2000: 141).

Orman köylerinin kalkındırılması amacıyla ayni ve nakdi destek sağlanarak üretkenliklerinin artırılacağı, sosyal ve ekonomik refah seviyelerinin iyileştirileceği de beyan edilmektedir. Kırsal kesimin ekonomik yönden güçlendirilmesi için kooperatif organizasyonları altında teşkilatlanmasının sağlanacağı ve kooperatiflerin teknik ve mali yönden destekleneceği ifade edilmektedir (DPT, 2000: 186). 


\subsubsection{Dokuzuncu Kalkınma Planı (2007-2013)}

Dokuzuncu planda orman köylerine veya orman köylüsüne direkt olarak değinilmemektedir. Kırsal kesimde kalkınmanın sağlanması için bu yerlerde, e-ticaret de kullanılarak, tarım, orman ve gıda ürünlerinin tanıtım ve pazarlanması, turizm ve rekreasyon, el sanatları, tarıma dayalı sanayi ve diğer alternatif üretim faaliyetleri geliştirileceği ifade edilmektedir (DPT, 2006: 93). Ancak kırsal kalkınmanın sağlanması için yapılması planlanan bu faaliyetler hakkında ayrıntılı bir bilgi yer almamaktadır.

\subsubsection{Onuncu Kalkınma Planı (2014-2018)}

Planda orman köylerine sadece kırsal kalkınma politikalarının olduğu bölümde değinilmektedir. Burada, başta orman köyleri olmak üzere, milli parklar gibi korunan alanların içinde veya civarında kalan köyler ile dağ köylerinin dezavantajlı konumlarından kaynaklanan kalkınma sorunlarını azaltmaya yönelik üretim ve gelir tabanlı destek araçlarının geliştirilmesi hedeflenmektedir (KB, 2013: 136).

\subsubsection{On Birinci Kalkınma Planı (2019-2023)}

On Birinci Kalkınma Planı (2019-2023) Cumhurbaşkanlığı Hükümet Sisteminin ilk kalkınma planıdır. 15 yıllık bir perspektifin ilk beş yıllık dilimi olarak tasarlanmıştır. Planda tarım, turizm ve savunma sanayii öncelikli gelişme alanları olarak belirlenmiştir. Ormancılıkla ilgili politika ve tedbirlere de tarım başlığı altında yer verilmiştir.

"Sürdürülebilir orman yönetimiyle ormanların ekonomiye katkısı arttırılacaktır” temel politikası içinde beş hedef belirlenmiştir. Bunlardan birisi orman köylüleriyle ilgilidir. Burada belirli programlar dâhilinde orman köylülerinin desteklenmesine devam edileceğinden bahsedilmektedir. Ancak bu programların neler olduğuna değinilmemiştir. Ayrıca, ormancılıkta kaliteli üretimin ve işgücü veriminin arttırılması için eğitim faaliyetleri ile profesyonelleşmenin arttırılacağına da değinilmektedir (SBB, 2019: 96).

\subsection{Orman Köylüsüne İlişkin Hedeflerdeki Değişim}

Kalkınma planlarında beşinci plandan sonraki her yeni planda orman köylerine ayrılan yer miktarının azaldığ1 üstteki bölümde net olarak görülmektedir. Her yeni planda orman köylerine azalan ilginin yanı sıra orman köyleriyle ilgili hedefler de değişmektedir. Hedeflerin çoğunda; ormanlar ve ormancılık etkinliklerinden orman köylüsüne fayda sağlanmasına yönelik öneriler vardır. Fakat ifade edilme şekilleri değişmekte veya zaman geçtikçe hedefler içinde yeni oluşmuş, güncel kavramlara yer verilmektedir. İlk kalkınma planında "halk orman ilişkileri düzenlenecek" gibi genel bir ifadenin yanı sıra "Orman yolu yapımı, üretim ve taşıma işlerinde orman köylüsü istihdam edilecektir” şeklinde orman köylüsünün istihdamına yönelik bir ifade vardır. Bu ifadeler ikinci planda aynen korunmuş ve orman köylüsünün istihdamına yönelik altı farklı alan daha spesifik olarak tanımlanmıştır. Bunların dışında ikinci planda orman köylerinde verilen kredilerin etkili ve gerçekçi bir düzene bağlanacağı, orman köylüsünün mesleğe yönelme eğitimi programlarına katılmasına öncelik verileceği ve orman kadastrosunun yapılacağı belirtilmektedir (Tablo 3). Türkiye'de 1970'li yılların başından itibaren tekniker okulları, endüstri meslek liseleri, kız meslek liseleri gibi okullardaki programlarla çeşitli meslek alanlarında endüstrinin ihtiyaç duyduğu mesleki formasyonlar verilmeye çalışılmıştır (MEB, 2019: 262). Bu şekilde o zamana kadar ağırlıklı olarak tarımda istihdam edilen nüfusun tarım dışındaki sektörlerde de istihdamın edilmesinin önü açılmış, böylelikle ülkenin ekonomik, sosyal ve kültürel kalkınmasına da bulunulmuştur. Buradaki mesleğe yönelme eğitimi ifadesiyle de bu durumun kastedildiği düşünülmektedir.

İlk kez birinci planda yer alan "Halk orman ilişkileri düzenlenecek" ifadesi son kez üçüncü planda yer almıştır. Üçüncü planda orman köylerindeki ev ve el sanatlarının desteklenmesi ve bunun örgütlü bir çalışma haline getirilmesi, önceki planda olduğu gibi orman kadastrosunun yapılması, ormanların yapısının iyileştirilmesi, orman köylüsüne verilen kanuni hakların işlenmiş ürün veya para olarak verilmesi ve orman köyleriyle çalışan kurumların arasındaki eşgüdümün sağlanması hedefleri yer almaktadır. Başlangıçtan beri hep ihmal edilen eşgüdüm konusu daha sonra yalnız altıncı planda yer almıştır. Fakat bu planda eşgüdümün sadece orman ve köy yolları yapımı ve bakımına indirgendiği görülmektedir. 
Tablo 3. Kalkınma planlarındaki orman köylüleriyle ilgili hedefler.

\begin{tabular}{|c|c|c|c|c|c|c|c|c|c|c|c|}
\hline Hedefler & $\mathbf{I}$ & II & III & IV & $\mathbf{V}$ & VI & VII & VIII & IX & $\mathbf{X}$ & $\overline{\mathbf{X I}}$ \\
\hline Orman köylerinde kooperatifçiliğin teşvik edilmesi & $\varnothing$ & $\varnothing$ & $\varnothing$ & $\varnothing$ & & & & $\varnothing$ & & & \\
\hline $\begin{array}{l}\text { Orman işletmeciliğinde ve orman ürünlerinin } \\
\text { değerlendirmesinde kooperatiflerin etkinliğinin arttırılması }\end{array}$ & & & & $\widetilde{\varnothing}$ & & & & & & & \\
\hline $\begin{array}{l}\text { Kooperatiflerin ormancılık faaliyetlerinde köylü ile devlet } \\
\text { arasındaki iş birliğini sağlayan araç olarak kullanılması }\end{array}$ & & & & $\varnothing$ & & & & & & & \\
\hline $\begin{array}{l}\text { Orman köylüsünün orman ürünlerini her aşamada } \\
\text { değerlendirme olanaklarının geliştirilmesi }\end{array}$ & & & & $\varnothing$ & & & & & & & \\
\hline Orman köylüsü ile orman işletmesi arasında iş birliği & & & & $\varnothing$ & & & & & & & \\
\hline $\begin{array}{l}\text { Ormanların korunması, } \\
\text { yetiştirilmesinde } \\
\text { özendirilmesi }\end{array}$ & & & & $\varnothing$ & & & & & & & \\
\hline $\begin{array}{l}\text { Köykentler yoluyla kırsalda ormancıllı̆a dayalı sanayi } \\
\text { yatırımlarının geliștirilmesi }\end{array}$ & & & & $\varnothing$ & & & & & & & \\
\hline Halk-orman ilişiklerinin düzenlenmesi & $\varnothing$ & $\varnothing$ & $\varnothing$ & & & & & & & & \\
\hline $\begin{array}{l}\text { Orman yolu yapımı, üretim ve taşıma işlerinde orman } \\
\text { köylüsü istihdamı }\end{array}$ & $\varnothing$ & $\varnothing$ & & & & & & & & & \\
\hline $\begin{array}{l}\text { Orman işletme, 1slah ve tesis çalışmalarında, su kontrolü ve } \\
\text { toprak koruması işlerinde orman köylüsünün istihdamı ve bu } \\
\text { konuda örgütlenmelerin sağlanması }\end{array}$ & & $\varnothing$ & & & & & & & & & \\
\hline İstihdam yaratmada orman köylerine öncelik & & $\varnothing$ & & & & & & & & & \\
\hline Hayvancılıkla ilgili çalışmalarda orman köylerine öncelik & & $\varnothing$ & & & & & & & & & \\
\hline Mera 1slahı çalışmalarında orman köylerine öncelik & & $\widetilde{\varnothing}$ & & & & & & & & & \\
\hline $\begin{array}{l}\text { Yem bitkisi yetiştirme çalışmalarında orman köylerine } \\
\text { öncelik }\end{array}$ & & $\widetilde{\varnothing}$ & & & & & & & & & \\
\hline $\begin{array}{l}\text { Orman köylerinde el ve ev sanatları ürünleri desteklenmesi } \\
\text { ve bu konuda örgütlenmenin sağlanması }\end{array}$ & & $\varnothing$ & $\varnothing$ & & & & & & & & \\
\hline $\begin{array}{l}\text { Orman köylüsüne verilen kredilerde etkili ve gerçekçi bir } \\
\text { düzen }\end{array}$ & & $\varnothing$ & & & & & & & & & \\
\hline Orman köylerinde mesleğe yönelme eğitimlerinde öncelik & & $\varnothing$ & & & & & & & & & \\
\hline Orman kadastrosunun yapılmas 1 & & $\varnothing$ & $\varnothing$ & & & & & & & & \\
\hline Orman mülkiyeti belirsizliğinin ortadan kaldırılması & & & & $\varnothing$ & & & & & & & \\
\hline Ormanların yapısının iyileştirilmesi & & & $\varnothing$ & & & & & & & & \\
\hline $\begin{array}{l}\text { Orman köylüsüne verilen kanuni hakların hammadde yerine } \\
\text { işlenmiş ürün veya para karşıllı̆ıını verilmesi }\end{array}$ & & & $\varnothing$ & & & & & & & & \\
\hline $\begin{array}{l}\text { Sektör ana planlarında da belirtilerek orman köyleriyle ilgili } \\
\text { çalışan kuruluşlar arasında eşgüdümün sağlanması }\end{array}$ & & & $\varnothing$ & & & & & & & & \\
\hline $\begin{array}{l}\text { Orman ve köy yolları yapımı ve bakımında kuruluşlar } \\
\text { arasında eşgüdümün sağlanması }\end{array}$ & & & & & & $\varnothing$ & & & & & \\
\hline $\begin{array}{l}\text { Özel ağaçlandırma çalışmaları ve orman köylüsüne yönelik } \\
\text { diğer sosyoekonomik faaliyetlerin devletçe teşvik edilmesi }\end{array}$ & & & & & $\varnothing$ & & & & & & \\
\hline $\begin{array}{l}\text { Köylünün kalkındırılmasının teknik, ayni ve parasal } \\
\text { tedbirlerle desteklenmesi }\end{array}$ & & & & & & $\varnothing$ & & $\varnothing$ & & & \\
\hline Orman köylülerinin desteklenmesine devam edilmesi & & & & & & & & & & & $\varnothing$ \\
\hline $\begin{array}{l}\text { Orman işletmelerinin üretiminde eğitim faaliyetleri ve } \\
\text { profesyonelleşmenin arttırılması }\end{array}$ & & & & & & & & & & & $\varnothing$ \\
\hline Ormanların ekonomiye katkısının arttırılması & & & & & & & & & & & $\varnothing$ \\
\hline $\begin{array}{l}\text { Orman köylülerinin kalkındırmasıyla ilgili kanunda } \\
\text { değișiklikler yapılarak orman vasfını yitirmiș alanların satıșı }\end{array}$ & & & & & & & $\varnothing$ & & & & \\
\hline Özel ormanların kurulmasının teşvik edilmesi & & & & & & $\varnothing$ & $\varnothing$ & $\varnothing$ & & & \\
\hline $\begin{array}{l}\text { Tarımsal ve sosyal ormancılı faaliyetlerinin } \\
\text { yaygınlaştırılması ve desteklenmesi }\end{array}$ & & & & & & $\varnothing$ & & & & & \\
\hline Sosyal ve toplumsal ormancılığın desteklenmesi & & & & & & & $\varnothing$ & & & & \\
\hline $\begin{array}{l}\text { Tarımsal ve sosyal ormancılık faaliyetlerinin geliştirilmesi } \\
\text { (meşe, akasya, fistık çamı vb. türlerle) }\end{array}$ & & & & & & & & $\varnothing$ & & & \\
\hline Odun dişı orman ürünleri üretiminin geliştirilmesi & & & & & & & & $\varnothing$ & & & \\
\hline Bıçkı sanayiinin yöresel ișletmelerle ile yürütülmesi & & & & & & $\varnothing$ & & & & & \\
\hline $\begin{array}{l}\text { Orman köylerinde, özellikle de korunan alanlardakilerde } \\
\text { üretim ve gelir tabanlı destek araçlarının geliştirilmesi }\end{array}$ & & & & & & & & & & $\varnothing$ & \\
\hline $\begin{array}{l}\text { Kırsalda tarım, orman ve gida ürünlerinin tanitım ve } \\
\text { pazarlanması ile alternatif üretim faaliyetlerinin } \\
\text { geliştirilmesi }\end{array}$ & & & & & & & & & $\varnothing$ & & \\
\hline
\end{tabular}


Dördüncü planda, önceki plandaki “orman kadastrosu yapılacaktır” ifadesinin yerini "Orman mülkiyeti belirsizliği ortadan kaldırılacaktır" ifadesi almıştır. Bu planlardan sonra kadastro veya mülkiyet konusuna bir daha dönülmemiş, sadece yedinci planda 2/B denmemiş olsa bile "orman vasfinı yitirmiş ve kentleşmiş olan alanların satılmak suretiyle" gelir sağlanması şeklinde bir ifade yer almıştır. Dördüncü planda, ilk üç planda ve daha sonra sekizinci planda yer alan "orman köylerinde kooperatifçilik teşvik edilecek” ifadesiyle yetinilmeyerek, orman işletmeciliğinde ve orman ürünlerinin değerlendirmesinde kooperatiflerin etkinliğinin arttırılacağı, kooperatiflerin ormancılık faaliyetlerinde köylü ile devlet arasındaki iş birliğini sağlayan araç olarak kullanılacağı belirtilmiş ve böylece bu plan kooperatifçiliğe en fazla önem verilen kalkınma planı olmuştur. İlk dört plan ve sekizinci plan dışında kalan altı planda orman köylerindeki kooperatifçiliğe hiç yer verilmemiş olması da oldukça düşündürücüdür. Gümrük ve Ticaret Bakanlığı’nın resmi verilerine göre ülke genelinde 7.201 tarımsal kalkınma kooperatifinde 775.563 ortak bulunmaktadır (GTB, 2017: 13). Bu kooperatiflerden 165.791 ortağa sahip 1.506 birim kooperatif Ormancılık Kooperatifleri Merkez Birliği çatısı altında toplanabilmiştir (ORKOOP, 2020). Orman Genel Müdürlüğü’nün resmi kayıtlarına göre 2018 yılı sonu itibariyle 22.847 orman köyünde 6.827 .500 orman köylüsünün yaşadığı (OGM, 2020) düşünüldüğünde kırsal kalkınmada önemli bir araç olarak kabul görmüş olmasına rağmen kooperatifçiliğin orman köylerinde pek yaygınlaştırılamadığı açıkça görülmektedir. Üstüne üstlük var olan ormancılık kooperatiflerinin de pazarlamadan aktif ortakların sayısının azlığına, tek tip işten eğitimlerdeki yetersizliğe kadar birçok sorunla karşı karşıya olduğu bildirilmektedir (Günşen, 2006; Atmiş vd., 2009; Toksoy vd., 2009; Alkan ve Demir, 2013; Korkmaz ve Gürer, 2018). Ormancılık kooperatiflerine verilen destekler değerlendirildiğinde ise yıllar içinde sürekli bir düşüşün olduğu görülmektedir. Öyle ki 1989 2003 yılları arasında yılda ortalama 30 kooperatif projesine yıllık ortalama 20.001.724 TL destek sağlamışken, bu rakamlar 2004 - 2018 yılları arasında yıllık ortalama 12 kooperatif projesinin yıllık ortalama 4.062.336 TL ile desteklenmesine kadar düşmüştür (OGM, 2020). Ne yazık ki tüm bu değerlendirmeler, az da olsa kalkınma planlarında yer alan ormancılık kooperatifleriyle ilgili hedeflerin başarıyla yerine getirilemediğinin göstergesidir.

Dördüncü planda ayrıca; orman köylüsü ile orman işletmesi arasında iş birliğinin sağlanacağı, ormanların korunması, geliştirilmesi ve yenisinin yetiştirilmesinde orman köylüsünün katkısının özendirileceği ve köykentler yoluyla kırsalda ormancılığa dayalı sanayi yatırımlarının geliştirileceği yer almaktadır. Kalkınma planlarında köykentlerle orman köylerini ilişkilendiren tek plan dördüncü plandır.

Beşinci planda sadece “Özel ağaçlandırma çalışmaları ve orman köylüsüne yönelik diğer sosyoekonomik faaliyetler devletçe teşvik edilecektir" ifadesi yer almaktadır. Bu ifadeyle, 24 Ocak 1980 Ekonomik Kararları sonrası küresel sermayenin bir parçası yapılmaya çalışılan ülke ekonomisi için, ormancılığın özel sektör boyutunun gündeme bu şekilde getirilmeye başlandığı anlaşılmaktadır. Planda orman köylüsüne dönük hangi sosyoekonomik faaliyetlerin teşvik edileceğine ilişkin bir açıklık yoktur. Altıncı ve sekizinci planlarda ise bu teşviklerin köylünün kalkındırılması için teknik, ayni ve parasal düzeyde yapılacağı belirtilmektedir. Altıncı planda ilk kez tarımsal ve sosyal ormancılık faaliyetlerinin yaygınlaştırılacağı ve destekleneceği bildirilerek dünyada da yaygınlaşmakta olan sosyal ormancılık anlayışı planlara dahil edilmiştir. Bu planda ayrıca bıçkı sanayiinin yöresel işletmelerle ile yürütülmesi yönünde bir öneri yer almaktadır. Yedinci planda aslında aynı anlama gelen "sosyal” ve "toplumsal” ormancılığın destekleneceği yönünde bir ifade kullanılmış, sekizinci planda tarımsal ve sosyal ormancılığın meşe, akasya, fıstık çamı vb. türlerle geliştirileceği belirtilmiştir.

Beşinci planda ilk kez gündeme gelen özel ağaçlandırma çalışmalarının teşvik edilmesi ifadesi, altıncı, yedinci ve sekizinci planlarda yerini; özel ormanların kurulmasının teşvik edilmesi ifadesine bırakmıştır. Böylece ormancılığın geldiği liberal anlayışa dayanan yeni aşamanın daha da güçlendirildiği görülmektedir. Dokuzuncu planda "Kırsalda tarım, orman ve gıda ürünlerinin tanıtım ve pazarlaması ile alternatif üretim faaliyetleri geliştirilecektir" denerek ilk kez orman köylerinde üretimin teşvik edilmesinden öte ürünlerin tanıtımı ve pazarlanması aşamalarına geçilmiştir. Bu ifadeden anlaşılacağı gibi; orman köyleri için odun üretimi dışında alternatif üretim faaliyetlerinin gündeme getirilmesi de bu planla olmuştur. Onuncu planda sadece özellikle korunan alanlara yakın orman köylerinde üretim ve gelir tabanlı destek araçlarının geliştirilmesinden bahsedilmiştir. Hangi şekilde olduğu belirtilmeden orman köylülerinin desteklenmesine devam edileceği iddiasında olan on birinci planda; üretimde eğitim faaliyetleri ve profesyonelleşmenin ve ormanların ekonomiye katkısının arttırılacağı söylenerek, ormanları küresel sermayenin emrine verecek şekilde oluşturulan yeni ormancılık anlayışı daha da pekiştirilmiştir.

\section{Sonuç ve Öneriler}

Türkiye'de kalkınma çalışmaları 1963 yılından beri planlı bir şekilde yürütülmektedir. Şimdiye kadar 10 kalkınma planı ömrünü tamamlamıştır. 15 yıllık bir perspektif planın ilk evresini oluşturan on birinci kalkınma planı ise 2019 yılında uygulanmaya başlanmıştır. Toplum içinde özel bir yeri olan orman köylüsünün 
kalkındırılmasıyla ilgili bazı durum analizleri ve politikalar yeterli düzeyde olmasa da bütün planlarda yer almıştır.

Kalkınma planlarının hem niceliksel hem de niteliksel değerlendirilmesi göz önünde bulundurulduğunda, 1985 1989 dönemi için hazırlanan Beşinci Kalkınma Planı'nın ülke kalkınma planlamasında kırılma noktası olduğu görülmektedir. Bunda 24 Ocak 1980 kararlarının ve ardından hükümetler tarafından benimsenen liberal ekonomi politikalarının önemli rolü vardır. Beşinci kalkınma planına kadar, planlarda orman köyü, orman köylüsü, köy kalkınması ve ormancılık kooperatiflerine az veya çok bir şekilde değinilirken, beşinci kalkınma planı ve sonraki planlarda artık bunlara çok daha az değinildiği ve yerlerine kırsal kalkınma, sürdürülebilir kalkınma, sosyal ormancılık, toplum ormancılığı, sürdürülebilir orman yönetimi gibi terimlerin kullanıldığı görülmektedir. Kısacası 1980’lerden sonra ülke kalkınma planlarında orman köylüsünün yeri giderek azalmıştır.

1963 yılındaki ilk plandan itibaren orman köylerinin yerleşim özelliklerinden dolayı orman köylüsünün içinde bulunduğu zor durum dile getirilmiş, ülkedeki kalkınma faaliyetlerine orman köylerinden başlanmasının gerekliliği vurgulanmıştır. Orman köylüsü, ormancılık mevzuatından doğan istihdam olanakları, fonlar, kooperatifleşme, köykent projeleri ve sosyal ormancılık uygulamaları gibi politika araçlarıyla bulundukları yerlerde kalkındırılmaya çalışılmıştır. Bunların oluşturulmasında planın hazırlandığı dönemdeki hükümetlerin ekonomik sisteme bakışının yanı sıra, dünyadaki ormancılık ve kırsal kalkınma eğilimlerinin de rolü olmuştur. Ancak gelinen noktada görülmektedir ki, oluşturulan politikaların uygulanmasında hep aksaklıklar yaşanmış, planlar arasında bir bağ kurulamamış ve neticede orman köylerinin kalkındırılmasında başarılı olunamamıştır. Türker vd. (2006: 284) bu başarısızlığın ormancılık sektörünün önemli darboğazlarından birini oluşturduğunu belirtmektedirler.

Genelde ülkenin kırsal kesiminde özelde ise orman köylerinde kalkınmayla ilgili oluşturulan politikaların uygulanamamasında hükümetlerin kısa süreli olmasının, iktidar ve bakanlık değişikliklerinin önemli rolü olduğu çeşitli araştırmacılar tarafından da dile getirilmiştir (Geray, 1999: 13; Coşkun vd., 2016: 108). Nitekim On Birinci Kalkınma Planında artık orman köylerinin kalkındırılmasından nerdeyse hiç bahsedilmez ve sadece ormanların ülke ekonomisine katkısından söz edilir hale gelmiştir. Bunda 2002 yılından beri iktidarı tek başına elinde bulunduran iktidarın doğal varlıkların korunmasını ve bu varlıklara bağlı yaşayan toplulukları göz önünde bulundurmadan oluşturduğu sosyal planlamadan yoksun ekonomik büyüme politikalarının rolü bulunmaktadır. Oysa Yurdakul Erol ve Yıldırım (2017) ekonomik faaliyetlerin kırsal kalkınma sürecinde kilit faktörlerden birisi olmasına karşın çevresel ve sosyo-kültürel boyutun da mutlaka dikkate alınması gerektiğini bildirmektedir.

Türkiye'de kalkınma planları yapılırken konulan hedefler ve bu hedeflerin uygulanması iktidarda bulunan siyasi partilerin düşünce ve programlarına göre değişmektedir (Güven, 1995: 38). Bu durum planlarda dönem dönem karma ekonomik sisteme ya da liberal kapitalist sisteme yakın politikaların yer almasına ve uygulanmasına neden olmuştur. Ülke ekonomisi içinde yer alan önemli sektörlerden biri olan ormancılık da hükümetlerin siyasal eğilimlerinden farklı şekillerde etkilenmektedir (Atmiş ve Günşen, 2016: 587). Liberal kapitalist ekonomi politikalarının yoğunluk kazandığı dönemlerde, orman köylerini de kapsayan kırsal kalkınma çalışmaları gibi sosyal planlamayla ilgili faaliyetlerin de göz ardı edildiği görülmektedir.

Toplumun ormanlardan beklentilerinin çeşitlenerek arttığı günümüzde ormanlardan elde edilecek mal ve hizmetlerin üretiminde insan gücüne hiç olmadığı kadar ihtiyaç vardır. Bu beklentileri karşılamada iş gücü olarak hiç şüphesiz ki orman köylüsüne de önemli roller düşmektedir: Korunan alanlarda yürütülecek doğa turizmi faaliyetlerinde, önemi her geçen daha da artan odun dışı orman ürünlerinin değerlendirilmesinde ve iklim değişikliğiyle ilgili kırsal alanlarda yapılacak etkinliklerde orman köylüsünün yer alması büyük önem taşımaktadır. Orman köylüsünün sürece dahil olmasıyla bir yandan toplumsal gereksinimler karşılanacak diğer yandan da orman köylüsünün kalkındırılmasına destek olunabilecektir. Bu doğrultuda ülke kalkınmasının planlanmasında orman köylüsünün de gözetildiği sosyal ve kültürel nitelikleri ağır basan bir planlama anlayışının tekrar ele alınması gerekmektedir. Ancak, yaklaşık 60 yıllık süreçte ülkenin kırsal kesiminde yaşananlara benzer şekilde orman köylerinin de demografik yapısının değiştiği ve planlamada bunun mutlaka göz önünde bulundurulması gerektiği unutulmamalıdır. Ayrıca, 2014 yılında yürürlüğe giren Büyükşehir yasasıyla büyükşehirlerin mücavir alanları genişlemiş, daha önce köy olan yerleşim birimleri mahalleye dönüşmüştür (Özensel, 2015: 35). Bu durum orman köylerinde de yaşanmış ve yeni bir terim olarak “orman mahalleleri” ortaya çıkmıştır. Mahalleye dönüşen bu köylerin önümüzdeki yıllarda kentsel bütünleşmeyle birlikte yeni kentleşme sorunlarıyla karşı karşıya kalacağı beklenmektedir. Bundan dolayı orman köylüsünün kalkındırılması kentleşme sorunlarının çözümünde de önemli bir yer tutmaktadır. Bu nedenle ülke kalkınma planlarında orman köylülerine sadece kırsal kalkınma konusunda değil, kentleşme sorunlarını çözümünde de öncelikli yer verilmelidir. 


\section{Teşekkür}

Makalemizi değerlendiren değerli üç anonim hakeme teşekkür ederiz.

\section{Kaynaklar}

1. Akesen, A., Ekizoğlu, A. (2010a). “Orman”, Akesen, A. ve Ekizoğlu, A. (Ed.), Ormancılık Politikası, Türkiye Ormancılar Derneği Yayını, Ankara, s. 1-18.

2. Akesen, A., Ekizoğlu, A. (2010b). "Ormancıllk", Akesen, A. ve Ekizoğlu, A. (Ed.), Ormancılık Politikası, Türkiye Ormancılar Derneği Yayını, Ankara, s. 19-36.

3. Alagöz. M., Yapar, S. (2003). Kalkınma planları çerçevesinde Türkiye'de sosyal güvenlik sorunu. Selçuk Üniversitesi Sosyal Bilimler Enstitüsü Dergisi, 10: 439-451.

4. Alkan, H., Demir, E. (2013). Orman Köylerinde Kooperatifçiliğin Gelişimine Etki Eden Etmenler. SDÜ Orman Fakültesi Dergisi, 14: 1-9.

5. Anonim (1976). Ormancılık Ana Planı 1973-1995, T.C. Orman Bakanlığı Yayınları, Ankara.

6. Atmiş, E., Günşen, H. B., Özden, S. (2009). "Forest Cooperatives and Its Importance in rural Poverty Reduction in Turkey", XIII World Forestry Congress, Buenos Aires, Argentina, 18-23 October 2009, pp:111.

7. Atmiş, E., Günşen, H. B., Özden, S. (2010). "How Can Turkey’s Forest Cooperatives Contribute To Reducing Rural Poverty?", Unasylva, 234/235(61): 51-53.

8. Atmiş, E., Günşen, H. B. (2011). 2011 Genel seçimlerinde siyasi partiler ve ormancılık ilişkileri. Kastamonu Üniversitesi Orman Fakültesi Dergisi 11(2):191-204.

9. Atmiş, E., Günşen, H. B. (2016). "Political Parties and Forestry Relations in Turkey’s General Elections in 2015", Journal of the Faculty of Forestry Istanbul University, 66(2): 587-599.

10. Bayraktaroğlu, H. (1968). "Toplum Kalkınmasında Orman İçi Köyleri”, İstanbul Üniversitesi Orman Fakültesi Dergisi, B-18(2): 31-42.

11. Baytal, Y. (2007). Demokrat parti dönemi ekonomi politikaları (1950-1957). Ankara Üniversitesi Türk Inkllap Tarihi Enstitüsü Atatürk Yolu Dergisi, 40: 545-567.

12. Bowen, G.A. (2009). "Document analysis as a qualitative research method", Qualitive Research Journal, 9(2): 27-40.

13. Büyükşalvarcı, A., Şapcılar, M.C., Bayrakçı, S. (2016). Kalkınma planları kapsamında turizm endüstrisinin değerlendirilmesi. Selçuk Üniversitesi Sosyal ve Teknik Araştırmalar Dergisi, 11: 186-201.

14. Coşkun, A.K., Öztürk, A., Türker, M.F. (2016). "Türkiye'de Hükümetlerin Orman Kaynakları Yönetimi ve İşletmeciliğine Yönelik Bazı Uygulamaların İrdelenmesi (1961-2012 Dönemi”, Kastamonu Üniversitesi Orman Fakültesi Dergisi, 16(1): 96-110.

15. Çağlar, Y. (1979). Türkiye'de Ormancılık Politikası (Dün), Çă̆ Matbaası, Ankara.

16. Çağlar, Y. (2015). Türkiye'de Kamu Arazilerinin Yönetiminde Planlı Plansızlık. Sosyal Araştırmalar Vakfı Yayını, İstanbul.

17. Çolakoğlu, E. (2007). "Kırsal Kalkınma Problemlerine Bir Çözüm Arayışı Olarak Köy-Kent Projesi”, ZKÜ Sosyal Bilimler Dergisi, 3(6): 187-202.

18. Demir, O., Üzümcü, A. (2002). "Türkiye'de Yaşanan Ara Rejimlerin Sebepleri Üzerine Bir İnceleme”, G. U. İ.̇.B.F. Dergisi, 1/2002, s.155-182.

19. DPT(1963). Birinci Beş Yıl Kalkınma Planı (1963-1967), T.C. Başbakanlık Devlet Planlama Teşkilatı, Ankara.

20. DPT (1968). İkinci Beş Yıllık Kalkınma Planı (1968-1972), T.C. Başbakanlık Devlet Planlama Teşkilatı, Ankara.

21. DPT (1972). Üçüncü Beş Yıllık Kalkınma Planı (1973-1977), T.C. Başbakanlık Devlet Planlama Teşkilatı, Ankara.

22. DPT (1979). Dördüncü Beş Yıllık Kalkınma Planı (1979-1983), T.C. Başbakanlık Devlet Planlama Teşkilatı, Ankara.

23. DPT (1984). Beşinci Beş Yıllık Kalkınma Planı (1985-1989), T.C. Başbakanlık Devlet Planlama Teşkilatı, Ankara.

24. DPT (1989). Altıncı Beş Yıllık Kalkınma Planı (1990-1994), T.C. Başbakanlık Devlet Planlama Teşkilatı, Ankara.

25. DPT (1995). Yedinci Beş Yıllık Kalkınma Planı (1996-2000), T.C. Başbakanlık Devlet Planlama Teşkilatı, Ankara.

26. DPT (2000). Uzun Vadeli Strateji ve Sekizinci Beş Yıllık Kalkınma Planı (2001-2005), T.C. Başbakanlık Devlet Planlama Teşkilatı, Ankara. 
27. DPT (2006). Dokuzuncu Kalkınma Planı (2007-2013), T.C. Başbakanlık Devlet Planlama Teşkilatı, Ankara.

28. Erdönmez, C. (2005). "Köykent: Olumlu ve Olumsuz Yönleriyle Bir Kırsal Kalkınma Projesinin Çözümlemesi”, Süleyman Demirel Üniversitesi Orman Fakültesi Dergisi, A-2: 35-51.

29. Erdönmez, C. (2013). “2B Alanlarının Satışının Türkiye Ulusal Ormancılık Programı Açısından İrdelenmesi”. Kastamonu Üniversitesi Orman Fakültesi Dergisi, 13(2): 307-324.

30. Geray, A. U. (1986). Planlama Ders Notları (Basılmamış), İstanbul Üniversitesi Orman Fakültesi, İstanbul.

31. Geray, A. U. (1998). Orman Kaynaklarının Yönetimi, Devlet Planlama Teşkilatı Yayını, Ankara.

32. Geray, C. (1999). "Kırsal Kalkınma Yöneltileri, İlçe Yerel Yönetimi ve İlçe Köy Birlikleri Önerisi”, Çăgdaş Yerel Yönetimler, 8(2): 11-42.

33. GTB, (2017). T.C. Gümrük ve Ticaret Bakanlığı Türkiye Kooperatifçilik Raporu 2016. Ankara.

34. Gül, H. (2015). "Kamu Politikası Analizi, Yöntemleri ve Teknikleri”. Yasama Dergisi, 29: 5-31.

35. Günay, T. (2003). Ormancılı̆̆ımızın Tarihçesine Kısa Bir Bakış, Tarım Orkam-Sen Yayını, Ankara.

36. Gümüş, C. (1996). Orman Köyleri Kalkınma Planlarında Çok Boyutlu Yöntemlerden Yararlanma Olanaklarl (Gümüşhane İli Orman Köyleri Örneği), Ekspres Ofset, İstanbul.

37. Gümüş, C. (2004). Ormancılık Politikası (Cilt 1), Karadeniz Teknik Üniversitesi Matbaası, Trabzon.

38. Gümüș, C. (2018). Türk Orman Devrimi, Türkiye Ormancılar Derneği Yayını, Ankara.

39. Günşen, H. B. (2006). Batı Karadeniz Bölgesindeki Ormancılık Kooperatiflerinin Sorunları ve Çözüm Önerileri (Kastamonu Örneği), Yüksek Lisans Tezi (Yayınlanmamış), Zonguldak Karaelmas Üniversitesi Fen Bilimleri Enstitüsü Orman Mühendisliği Anabilim Dalı, Bartın.

40. Günşen, H. B. (2012). Orman Köylerinde İç Göçleri Etkileyen Faktörler (Bartın - Kastamonu Örneği), Doktora Tezi (Yayınlanmamış), Bartın Üniversitesi Fen Bilimleri Enstitüsü Orman Mühendisliği Anabilim Dalı, Bartın.

41. Günşen, H. B., Atmiş, E. (2017). Doğa turizmi master planlarının doğa turizmini geliştirmesindeki katkı düzeyi. 1. Uluslararası Sürdürülebilir Turizm Kongresi Bildiriler Kitab1. 23-25 Kasım 2017, Kastamonu, s:207-221.

42. Günşen, H.B., Atmiş, E. (2019). Analysis of forest change and deforestation in Turkey. International Forestry Review, 21(2): 182-194. DOI: https://doi.org/10.1505/146554819826606577

43. Güven, S. (1995). Türkiye'de Sosyal Planlama, Ezgi Kitabevi Yayınları, Bursa.

44. İnal, S. (1967). "Orman ve Ormancılık Problemlerimize Toplu Bir Bakış". İstanbul Üniversitesi Orman Fakültesi Dergisi, B-17(2): 31-44.

45. Kayıkçı, S. (2005). "Cumhuriyetin Kuruluşundan Günümüze Kadar Köy ve Köylüye Yönelik Olarak İzlenen Politikalar". Türk İdare Dergisi, 448: 69-99.

46. KB (2013). Onuncu Kalkınma Planı (2014-2018), T.C. Kalkınma Bakanlığı, Ankara.

47. Koç Konu, A. (2014). "Ekonomik Kalkınma Sürecinde Beşeri Sermayenin Rolü ve Türkiye Ekonomisi”, Bekmez, S. (Ed.), Farklı Boyutlarıla Türkiye'de Kalkınma, Efil Yayınevi, Ankara, s. 147-171.

48. Korkmaz, M., Gürer, D. (2018). Financial performance evaluation of forest village cooperatives: a multicriteria topsis approach. CERNE, 24(3): 280-287.

49. Küçüker, E. (2012). Türkiye'de kalkınma planları kapsamında yapılan eğitim planlarının analizi. Kastamonu Ĕ̈itim Dergisi, 20(1): 9-26.

50. MEB (2019). Geçmişten Günümüze Fotoğraflarla Mesleki ve Teknik Eğitim 11.YY - 21. YY. Milli Eğitim Bakanlığı Yayını, Ankara.

51. OGM (2020). Orman Genel Müdürlüğü http://www.ogm.gov.tr/ekutuphane/Sayfalar/Istatistikler.aspx (05.03.2020).

52. ORKOOP (2020). S.S. Türkiye Ormancıllk Kooperatifleri Merkez Birliği. http://www.orkoop.org.tr/kurulus4a.html (05.03.2020)

53. Özdönmez, M., İstanbullu, T., Akesen, A. (1989). Ormancllık Politikası, İstanbul Üniversitesi Orman Fakültesi Yayını, İstanbul.

54. Özdönmez, M., İstanbullu, T., Akesen, A., Ekizoğlu, A. (1996). Ormancılık Politikası, İstanbul Üniversitesi Orman Fakültesi Yayını, İstanbul.

55. Özensel, E. (2015). Türkiye'de Kırsal Yapıların Dönüşümü - Kır Sosyolojisi. Çizgi Kitabevi, Konya.

56. Özyurt, H. (1981). "Atatürk Dönemi Birinci ve İkinci Beş Yıllık Sanayileşme Planları ve Türk Ekonomisindeki Yapı Değişikliğine Etkileri”. Journal of Economy Culture and Society (Önceki adı Sosyoloji Konferanslarl), 19: 119-148.

57. Polatoğlu, M.G. (2017). “İkinci Beş Yıllık Sanayi Planı (1938-1942)”. Atatürk Dergisi, 6(1): 55-87.

58. Rega (1956). T.C. Resmi Gazete, Başbakanlık Mevzuatı Geliştirme ve Yayın Genel Müdürlüğü, Sayı. 9402, Ankara.

59. SBB (2019). On Birinci Kalkınma Planı (2019-2023), Türkiye Cumhuriyeti Cumhurbaşkanlığı Strateji ve Bütçe Başkanlığ 1 , Anakara, 209s. 
60. Soyak, A., Eroğlu, N. (2008). “Türkiye'nin Kalkınma Anlayışının Dönüşümünde IMF-Dünya Bankası Yapısal Uyum Politikalarının Rolü”, Küreselleşme, Demokratikleşme ve Türkiye Uluslararası Sempozyumu, 27-30 Mart 2008, s: 526-535.

61. Takım, A. (2011). Türkiye'de 1960-1980 yılları arasında uygulanan kalkınma planlarında maliye politikalar1. Maliye Dergisi, 160: 154-176.

62. Takım, A. (2012). Demokrat parti döneminde uygulanan ekonomi politikaları ve sonuçları. Ankara Üniversitesi SBF Dergisi, 67(2): 157-187.

63. Tecer, M. (2006). “Atatürk Döneminde (1923-1938) Ekonomik Örgütlenme”, Amme İdaresi Dergisi, Cilt 39, sayı 4, s. 75-116.

64. Toksoy, D., Yenigün, M., Şen, G. (2009). Orman Köylerindeki Tarımsal Kalkınma Kooperatiflerinin Swot Analizi İle Değerlendirilmesi (Maçka İlçesi Örneği). Kastamonu Üniversitesi Orman Fakültesi Dergisi, 9(1): 12-18.

65. Tolunay, A., Korkmaz, M. (2003). “Kalkınma, Kırsal Kalkınma ve Katılımc1lık”, II. Ulusal Ormancılık Kongresi, 19-20 Mart, Ankara.

66. TUOP, (2004). Türkiye Ulusal Ormancılık Programı 2004-2023. Çevre ve Orman Bakanlığı Yayını, Ankara.

67. TüIKK, (2020). Türkiye İstatistik Kurumu Adrese Dayalı Nüfus Kayıt Sistemi. https://biruni.tuik.gov.tr/medas/?kn=95\&locale=tr (05.03.2020).

68. Türkdoğan, O., Gökçe, O. (2012). Sosyal Bilimlerde Araştırma Yöntemi, Çizgi Kitabevi Yayınları, Konya.

69. Türker, M.F., Genç, C., Aydın Yeni, F. (2006). Beş Yıllık Kalkınma Planları Yardımı İle Ülkemiz Ormancılığının Sosyo-Ekonomik Kapsamlı Sorunları ve Bu Sorunları Doğuran Kök Sorunların İrdelenmesi. Ormancılıkta Sos-Ekonomik Sorunlar Kongresi, Çankır1, S:281-289.

70. Türker, M.F., Pak, M., Öztürk, A. (2000). The Review of Non-Wood Forest Products Management in Turkey as From The Five Year Development Plans and Forestry Main Plans. Harvesting of Non-Wood Forest Products Seminar Proceedings, İzmir, S:307-313.

71. Tüzünkan, D. (2015). "Türkiye'de Uygulanan Beş Yıllık Kalkınma Planlarının İstihdam Politikaları Açısından Değerlendirilmesi”, Beykent Üniversitesi Sosyal Bilimler Dergisi, 8(2), s.6-31.

72. Uçkaç, A. (2010). "Türkiye'de Neoliberal Ekonomi Politikaları ve Sosyo-Ekonomik Yansımaları", Maliye Dergisi, Sayı 158, Ocak-Haziran, s. 422-430.

73. Yanar, R. (2014). "Kalkınma Ekonomisinin Kapsamı, Kalkınma Sürecinin Ölçülmesi ve Kalkınma Sürecini Belirleyen Etkenler”, Bekmez, S. (Ed.), Farklı Boyutlarılla Türkiye'de Kalkınma, Efil Yayınevi, Ankara, s. 1-18.

74. Yeşilbaş, M. (2011). "Kırsal Kalkınma Politikalarının Gelişim Çizgisi ve Planlı Dönemde Kırsal Kalkınma Yaklaşımları”, Türk İdare Dergisi, 470: 153-176.

75. Yurdakul Erol, S. (2018). Interactions between Forest Policy, Education and Research in Turkey: Policy Documents' and Managers' Perspectives. Baltic Forestry, 24(2): 320-331.

76. Yurdakul Erol, S., Yıldırım, H.T. (2017). A qualitative and quantitative analysis of Turkish forest policy documents in the rural development scope. Ciencia Rural, 47(6): 1-9.

77. Yücel, F. (Ed.) (2014). Cumhuriyet Türkiye'sinin Sanayileşmede İlk Önemli Adımı: Birinci Beş Yıllık Sanayi Planı 1934-1938, TMMOB Elektrik Mühendisleri Odası, Ankara. 